\title{
Justice Kennedy and the Unfolding Doctrine of Corporate Religious Sincerity
}

\section{Citation}

Spencer Churchill, Justice Kennedy and the Unfolding Doctrine of Corporate Religious Sincerity (May 21, 2015).

\section{Permanent link}

http://nrs.harvard.edu/urn-3:HUL.InstRepos:24708400

\section{Terms of Use}

This article was downloaded from Harvard University's DASH repository, and is made available under the terms and conditions applicable to Other Posted Material, as set forth at http:// nrs.harvard.edu/urn-3:HUL.InstRepos:dash.current.terms-of-use\#LAA

\section{Share Your Story}

The Harvard community has made this article openly available.

Please share how this access benefits you. Submit a story.

\section{Accessibility}




\section{Justice Kennedy and the Unfolding Doctrine of Corporate Religious Sincerity}

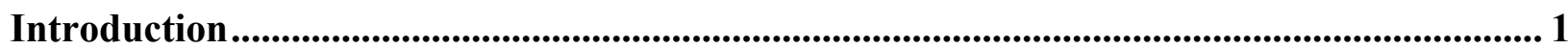

I. The Story As It Stands: Supreme Court Precedents Regarding the Relevance of

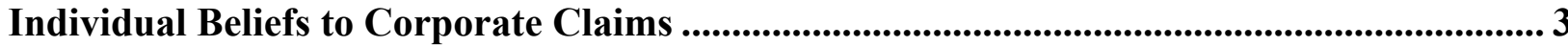

A. Ambiguity About Whether Individual Beliefs Are Relevant as the Beliefs of Individuals or

As Beliefs Attributable to Corporations ................................................................................. 3

1. The Rhetoric in Hobby Lobby Suggests the Beliefs of Individuals Are Relevant As Such 4

2. The Doctrinal Analysis in Hobby Lobby Suggests the Beliefs of Individuals Are Relevant

Because Attributable to Corporations

3. The Rhetoric and Analysis in the Nonprofit Cases Suggest That Corporations Have

Legally Cognizable Religious Beliefs .......................................................................... 10

B. Ambiguity About Which Individuals' Beliefs Are Relevant ........................................ 15

II. The Next Chapter in a Liberal Narrative ............................................................................ 20

A. The Narrative: Corporate Claims Are Justified to Protect Individuals Who Care About

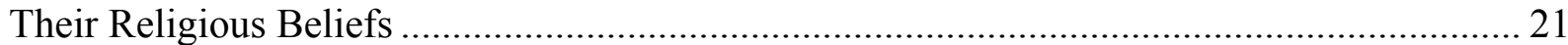

B. The Doctrinal Test of Sincerity: Balancing the Beliefs of Individuals .............................. 24

C. The Fit With Current Doctrine: Strong on Rhetoric, Weak on Substance......................... 27

III. The Next Chapter in an Originalist Narrative ...................................................................... 28

A. The Narrative: Corporate Claims Are Justified to Protect Corporations That Are Under

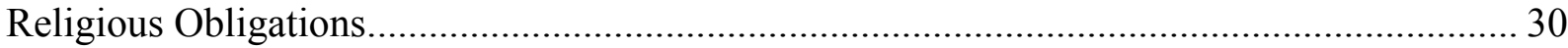

B. The Doctrinal Test of Sincerity: Identifying the Beliefs of Corporations........................... 32

C. The Fit With Current Doctrine: Weak on Rhetoric, Strong on Substance.......................... 38

IV. The Next Chapter in Justice Kennedy's Hybrid Narrative................................................ 39

A. The Narrative: Corporate Claims Are Justified to Protect the Right of Individuals Involved

With Corporations to Strive to Follow Their Religious Beliefs ........................................... 41

B. The Doctrinal Test of Sincerity: Understanding the Nexus of Individual Beliefs and

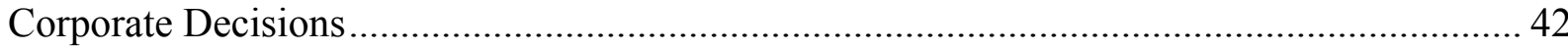

C. The Fit With Current Doctrine: Strong on Rhetoric and on Substance ............................ 44

V. The Originalist and Hybrid Doctrines of Corporate Sincerity Are More Manageable Than the Liberal Balancing Doctrine ......................................................................................... 45

A. The Relevance of the Beliefs of Owners ................................................................... 45

B. The Relevance of the Beliefs of Directors and Managers.................................................. 53

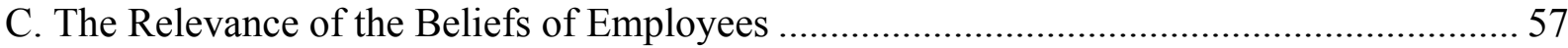

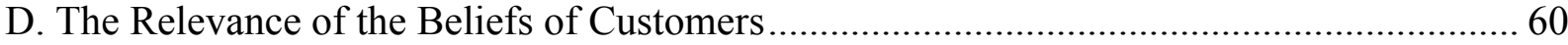

E. The Relevance of the Beliefs of Founders ...................................................................... 62

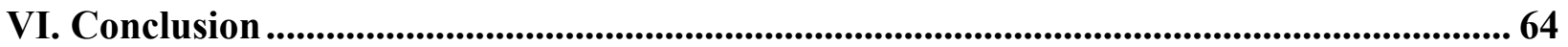




\title{
Justice Kennedy and the Unfolding Doctrine of Corporate Religious Sincerity
}

\author{
Spencer Churchill ${ }^{1}$
}

INTRODUCTION

Justice Ginsburg rightly noted that the Supreme Court's decision in Burwell v. Hobby

$L o b b y^{2}$ left many questions unanswered. ${ }^{3}$ For example, how should courts assess corporate

religious liberty claims when a corporation's owners or shareholders disagree with each other? ${ }^{4}$

How should courts assess claims based on the religious beliefs of directors and managers, ${ }^{5}$ of

employees, ${ }^{6}$ of customers, ${ }^{7}$ or of corporate founders $?^{8}$ Behind these questions lies a deeper

\footnotetext{
${ }^{1}$ The author would like to express his appreciation to the Harvard Law School Summer Academic Fellowship Program for funding the research behind this Article; to Mark Tushnet and Mary Ann Glendon, who provided consultation in connection with the fellowship; to the many others who reviewed drafts and discussed ideas as this Article developed; and to the Harvard Journal of Law \& Public Policy for allowing republication in Part I.B of this Article of analysis drawn from Spencer Churchill, Comment, Whose Religion Matters In Corporate RFRA Claims After Burwell v. Hobby Lobby Stores, 134 S. Ct. 2751 (2014)?, 38 Harv. J. of Law \& Pub. Pol. 437 (2015).

2134 S. Ct. 2751 (2014).

${ }^{3} I d$. at 2797 n.19 (Ginsburg, J., dissenting).

${ }^{4}$ For example, what if a religious majority of the owners desires an exemption to which the other owners are indifferent? Does it make a difference if the religious group happens to be a minority of the owners and it is the majority that is indifferent? What if a plurality agrees to seek an exemption based on different religious beliefs? And if beliefs that are not held by a majority of a corporation's owners can be relevant to the corporation's claim, what happens when a minority has a religious objection to the exemption sought by a majority? These questions are considered in turn in Part V.A, infra.

${ }^{5}$ For example, what if the directors and managers desire a religious exemption to which the owners are indifferent? Does it make a difference if a minority of the shareholders has a religious objection to the action the directors and managers desire to take? Would the religious beliefs of the minority shareholders matter more if the directors and managers had complied with those beliefs before seeking an exemption? These questions are considered in turn in Part V.B, infra.

${ }^{6}$ For example, what if Muslim bankers desire an exemption from a consumer protection law requiring them to state an effective rate of interest for every loan they issue but work in the Islamic banking division of a bank that is not owned, directed, or managed by Muslims? Does it make a difference if the employees in question are Muslim janitors at the bank who believe they should not work for a corporation that violates Islam's teaching against charging interest? These questions are considered in turn in Part V.C, infra.

${ }^{7}$ For example, what if a kosher butcher shop happens to be bought by non-Jews, who subsequently hire non-Jewish directors, managers, and employees but seeks an exemption on behalf of their Jewish customers from an animal cruelty law that effectively prohibits kosher slaughter? Does it matter if one of the employees is a cashier with religious objections to animal cruelty? These questions are considered in turn in Part V.D, infra.

${ }^{8}$ For example, what if a benefit corporation's founders establish a religious purpose or governing principle in the corporate charter? Does it make a difference if the founders have died and no one involved in the company shares the founder's beliefs? These questions are considered in turn in Part V.E, infra.
} 
problem: In a system that allows corporations to seek religious accommodations, what does it mean for a court to determine that a corporation's claim is based on sincere religious beliefs? Whose beliefs should corporate religious liberty claims protect? Answering these questions, to borrow an image from Ronald Dworkin, is like writing a new chapter in a chain novel—it requires interpreting the story that the law has already told about corporate religious liberty and crafting answers that fit the existing narrative and share its justifications. ${ }^{9}$ Justice Kennedy's Hobby Lobby concurrence suggests that existing law tells a hybrid narrative that combines the popular justification of the libera $1^{10}$ narrative with the doctrinal fit offered by the originalist, ${ }^{11}$ charting the path toward a manageable doctrine of corporate sincerity.

Part I of this Article explores the ambiguities in existing doctrine that make multiple narratives about corporate religious liberty plausible. Part II shows how the liberal narrative's popular justification of corporate standing suggests an unruly balancing approach to determinations of sincerity that fits poorly with existing law. Part III shows how the originalist narrative's complex and unpopular justification of corporate standing suggests a nuanced doctrine of sincerity that fits well with existing law. Part IV shows how the hybrid narrative can offer a more widely acceptable justification of corporate standing than the alternatives and combine it with the fit of the originalist doctrine of sincerity. Part V uses a series of hypotheticals to explore the practical implications of adopting various possible doctrines and to demonstrate that the doctrine flowing from Justice Kennedy's narrative allows courts to make intuitive

\footnotetext{
${ }^{9}$ R. DWORKIN, LAW'S EMPIRE, 228-38 (1986).

${ }^{10}$ This Article uses "liberal" not in the political sense but as a name for the family of ideas consistent with a conception of religious liberty grounded in human dignity. For an example of such an approach, see Douglas Laycock, Religious Liberty as Liberty, 7 J. Contemp. Legal Issues 313 (1996).

${ }^{11}$ This Article uses "originalist" as an umbrella term covering the family of ideas consistent with a conception of free exercise grounded in the idea that the state should allow religious exemptions in order to recognize duties owed to a deity with authority higher than that of the state. The use of the term "originalist" to describe this view is suggested by Michael W. McConnell, The Origins and Historical Understanding of Free Exercise of Religion, 103 Harv. L. Rev. 1409 (1990) but is contested in Philip A. Hamburger, A Constitutional Right of Religious Exemption: An Historical Perspective, 60 Geo. Wash. L. Rev. 915 (1992).
} 
distinctions in identifying which corporate claims protect sincere religious beliefs. Part VI concludes by arguing that the hybrid narrative should guide the development of the next chapter in corporate religious liberty.

\section{The Story As It Stands: Supreme Court Precedents Regarding the ReleVance of INDIVIDUAL BELIEFS TO CORPORATE CLAIMS}

Supreme Court precedent offers two sources of guidance in assessing what religious beliefs are relevant to a corporate religious liberty claim. First, the decision in Hobby Lobby shows how the Court has approached the claims of for-profit corporations under the Religious Freedom Restoration Act (RFRA). ${ }^{12}$ Second, several earlier decisions show how the Court has approached the claims of nonprofit corporations under the Free Exercise Clause and under RFRA. Hobby Lobby makes clear that for-profit corporations can have standing at least in the present American legal system, ruling out narratives about corporations that categorically bar them from seeking religious exemptions. Because nonprofit corporations do not have owners but can have standing, the nonprofit cases rule out narratives in which the religious beliefs of owners are essential to corporate standing. Beyond that, existing law leaves room for a range of narratives. It is not yet clear whether the protagonist in a corporate religious liberty claim is the individual or the corporation or what role should be played by individuals whose beliefs differ from the ones for which a corporation seeks accommodation.

\section{A. Ambiguity About Whether Individual Beliefs Are Relevant as the Beliefs of Individuals or As Beliefs Attributable to Corporations}

Although the nonprofit cases emphasized beliefs that governed corporate conduct and were therefore attributable to corporations, the rhetoric of Hobby Lobby put substantial emphasis

\footnotetext{
${ }^{12} 42$ U.S.C. $\S \S 2000 b b-2000 b b-4$ (2006).
} 
on individual beliefs. One explanation could be that the Supreme Court has decided that corporations are incapable of holding religious beliefs and is moving away from the rhetoric in its older decisions about nonprofit corporations. Another explanation would be that the Supreme Court considered individual beliefs relevant in Hobby Lobby because they were attributable to the corporation. The tension within the law makes it possible to tell a narrative in which the law is fundamentally concerned only with the religious beliefs and liberties of individuals or a narrative in which the law recognizes corporate claims out of concern for the religious beliefs and liberties of corporations.

1. The Rhetoric in Hobby Lobby Suggests the Beliefs of Individuals Are Relevant As Such Hobby Lobby held that the Department of Health and Human Services (HHS) violated RFRA when it sought to force closely held corporations operated by the Hahn and Green families to provide healthcare coverage for forms of contraception that the government stipulated could function as abortifacients. In doing so, it noted the belief of the Hahns and Greens that facilitating the destruction of human life by providing such coverage is wrong. Hobby Lobby provides the basis for three doctrinal arguments that individual beliefs are at the heart of corporate claims. First, the Supreme Court's introductory characterization of its position on standing directly states that for-profit corporations have standing for the purpose of vindicating individual religious liberty:

As we will show, Congress provided protection for people like the Hahns and Greens by employing a familiar legal fiction: It included corporations within RFRA's definition of "persons." But it is important to keep in mind that the purpose of this fiction is to provide protection for human beings .... When rights, whether constitutional or statutory, are extended to corporations, the purpose is to protect the rights of these people .... [P]rotecting the free-exercise rights of corporations like Hobby Lobby, Conestoga, and Mardel protects the religious liberty of the humans who own and control those companies. ${ }^{13}$

${ }^{13}$ Hobby Lobby, 134 S.Ct. at 2768. 
Second, the Supreme Court analogized the claims of for-profit corporations to those of nonprofits, noting that "furthering their religious freedom also 'furthers individual religious freedom." 14 Third, the Court's substantial burden analysis repeatedly mentioned the religious beliefs of the corporations' owners, ${ }^{15}$ reinforcing the idea that corporate claims exist for the purpose of vindicating individual rights and not for the purpose of vindicating any rights enjoyed by the corporations themselves. These arguments are strong, but not invincible.

Taking the arguments for a focus on individual beliefs in reverse order, consider first the observation that the religious beliefs of the Greens and Hahns figured prominently in the Court's substantial burden analysis. While this may be true in itself, it is important to note that the Court arguably did not consult their beliefs qua beliefs of individuals who desired an exemption. In legal terms, the exemption was requested by and granted to corporations and not to individualsa point that the Supreme Court reinforced when it vacated and remanded a D.C. Circuit decision refusing to allow a corporate claim for exemption but allowing individual claims. ${ }^{16}$ The Court may well have consulted the beliefs of the corporations' owners because, given the fact that the corporations were closely held and managed by the Greens and Hahns, it considered their beliefs attributable to their corporations. ${ }^{17}$ Because this is a plausible reading of Hobby Lobby, the fact that the Supreme Court gave much attention to individual beliefs in its substantial burden

\footnotetext{
${ }^{14}$ Id. at 134 S. Ct. at 2769.

${ }^{15}$ See id. at $2775-79$.

${ }^{16}$ Gilardi v. Dep't. of Health \& Human Servs., 733 F.3d 1208, 1214-16 (D.C. Cir. 2013), vacated and remanded by Gilardi v. Dep't of Health \& Human Servs., No. 13-567, 2014 WL 2931834 (U.S. July 1, 2014).

${ }^{17}$ See, e.g., Hobby Lobby, 134 S. Ct. at 2775 ("By requiring the Hans and Greens and their companies to arrange for such coverage, the HHS mandate demands that they engage in conduct that seriously violated their religious beliefs.") (emphasis added); id. at 2776 ("[T] he Hahns and Greens and their companies have religious reasons for providing health-insurance coverage for their employees.") (emphasis added); id. at 2777 ("We doubt that the Congress that enacted RFRA ... would have believed it a tolerable result to put family-run businesses to the choice of violating their sincerely held religious beliefs or making all of their employees lose their existing healthcare plans.") (emphasis added); id. at 2777 n.33 (referring to other employers "that have the very same religious objections as the Hahns and Greens and their companies") (emphasis added); id. at 2779 ("the Hahns and Greens and their companies sincerely believe that providing the insurance coverage demanded by the HHS regulations lies on the forbidden side of the line ....") (emphasis added).
} 
analysis does not foreclose a narrative in which corporate rights rather than individual rights lie at the heart of corporate religious liberty claims.

Consider next the Supreme Court's statement that allowing for-profit corporations to bring RFRA claims "furthers individual religious freedom."18 Read in context, this statement does not necessitate a narrative focused on individual rights. The Court made this statement in responding to what it took as the dissent's position that nonprofits are distinguishable from forprofits in that their claims further individual religious freedom. ${ }^{19}$ The Court observed that forprofit claims further individual rights in order to deny that this is a distinguishing factor, not in order to show that corporations ought to have standing. ${ }^{20}$ The statement identifies benefits to individuals as a consequence of recognizing corporate claims, but says nothing about whether this benefit justifies corporate standing or is merely incidental to a core purpose of allowing corporations to follow their religious beliefs.

Consider, finally, two responses to the Court's assertion in its introductory characterization of its holding that it would show how corporate claims are justified on the basis of individual religious liberty. First, even a narrative focused on corporate beliefs would identify those beliefs as the beliefs held by individuals who exercise control over the corporation's conduct $^{21}$ and could, in this limited sense, be characterized as deriving corporate rights from the protected religious practices of individuals. ${ }^{22}$ Second, although identification of a statement as

\footnotetext{
${ }^{18}$ Id. at 2769.

${ }^{19}$ Hobby Lobby, 134 S.Ct. at 2794 (Ginsburg, J., dissenting).

${ }^{20}$ It may be argued that the Court would not find this demonstration necessary unless the purportedly distinguishing factor cited by the dissent were pertinent to the standing analysis. While this interpretation is possible, an equally plausible interpretation is that the Court took the dissent's argument on its own terms in order to show its empirical inadequacy rather than delving into an unnecessary theoretical debate about what factors pertain to standing. The Court's statement, in itself, supports neither the proposition that individual rights lie at the heart of corporate claims nor the proposition that corporate rights constitute the core reason for corporate standing.

${ }^{21}$ See Part III.B, infra.

${ }^{22}$ Corporate law is familiar with the idea that a corporation may have rights derived from but also distinct from the rights of individuals. Courts have recognized a distinction between corporations and their constituents such that a
} 
dicta is fraught with peril, the Court's promise to show that individual rights justify corporate claims could be a prime candidate for the designation if the Court's substantive arguments did not in fact make this showing.

2. The Doctrinal Analysis in Hobby Lobby Suggests the Beliefs of Individuals Are Relevant Because Attributable to Corporations

Rather than showing that corporate claims are based on individual rights, the Hobby Lobby Court's substantive argument for standing provides three reasons to think that corporate claims are based on the right of corporations to follow their religious beliefs. First, the Court cited the Dictionary Act definition of "person" as a basis for interpreting RFRA to protect forprofit corporations and stated that it saw "nothing in RFRA that suggests a congressional intent to depart from the Dictionary Act definition. ${ }^{, 23}$ If the Court were telling a narrative in which corporate claims are simply vehicles for allowing individuals to follow their own religious beliefs, it would likely have given greater attention to the argument that RFRA only protects persons exercising religion and that only human beings exercise religion. ${ }^{24}$ Instead, the Court's ready acceptance of the assumption that a "person" under the Dictionary Act enjoys RFRA's protection suggests a narrative in which corporations themselves have cognizable beliefs.

Second, the most extended portion of the Court's analysis, by far, is dedicated to showing that for-profit corporations can exercise religion - a proposition that would be irrelevant to a narrative in which the relevant religious exercise is that of individuals. After establishing the

corporation may claim a right against directors for failing to pursue its interests - which are related to the interests of constituents - although no constituent or constituency has a right that it may claim against the directors. See, e.g., Credit Lyonnais Bank Nederland v. Pathe Commc'ns Corp., No. 12150, 1991 WL 277613 at*34 (Del. Ch. Dec. 30, 1991) (holding that, at least in zone of insolvency, directors owe duty to corporation and not to any constituency); Roselink Investors v. Shenkman, 386 F. Supp. 2d 209, 215 (S.D.N.Y. 2004) (quoting Credit Lyonnais, 1991 WL at *34). It is possible that corporations could have a right against the government that is similarly distinct from but related to any rights its constituents might claim.

${ }^{23}$ Hobby Lobby, 134 S.Ct. at 2768.

${ }^{24}$ See id. at 2793-96 (Ginsburg, J., dissenting). 
general proposition that religious and financial motives are not mutually exclusive, the Court provided three reasons for its position that for-profit corporations are no exception. ${ }^{25}$ The Court's first argument for its position that corporations can exercise religion was that state law permits them to pursue any legal purpose. ${ }^{26}$ In a narrative that assumed only individuals could exercise religion, the fact that religious purposes are not legally excluded from the activities in which corporations can engage would be easily explained by the fact that it never occurred to lawmakers to prohibit such an impossibility. ${ }^{27}$ The Court's conclusion that corporations can exercise religion only follows in a narrative that recognizes the possibility of corporations exercising religion.

The Court's second argument for its position that corporations can exercise religion used Hobby Lobby's statement of purpose and Conestoga Wood's statement of vision and values as examples of how for-profit corporations can "seek to perpetuate the religious values shared, in these cases, by their owners." 28 This argument treats corporate statements as indicative of a corporation's religious beliefs without concerning itself, at least in any explicit way, with the beliefs of individuals. ${ }^{29}$ Similarly, the Court noted without criticism that the statements of corporations indicate their religion in the system of nonprofit exemptions that the government should have made available to for-profits: In this system, “[a]n 'eligible organization' means a nonprofit organization that 'holds itself out as a religious organization' and 'opposes providing coverage for some or all of any contraceptive services required to be covered ... on account of religious objections."' In a narrative that denied the possibility of corporations having religious

\footnotetext{
${ }^{25}$ Hobby Lobby, 134 S.Ct. at 2769-74.

${ }^{26}$ Id. at $2770-72$.

${ }^{27}$ Spencer Churchill, Note, Duty or Dignity? Competing Approaches to Corporate Free Exercise, 37 HARV. J. OF LAW AND PUB. POL. 1171, 1183-85 (2014).

${ }^{28}$ Hobby Lobby, 134 S.Ct. at 2770 n.23 (internal quotes omitted).

${ }^{29} \mathrm{Id}$. at 2763 (quoting 45 CFR $\S 147.131(\mathrm{~b})$ ).
} 
beliefs, a corporation's claims to be religious are unintelligible. In the Court's analysis, such claims are vital.

The Court's third argument for its position that corporations can exercise religion was that benefit corporations are a type of for-profit corporation that can clearly exercise religion. ${ }^{30}$ This again reflects the understanding that corporations can have religious beliefs and articulate them in corporate statements. Additionally, it undermines the argument that corporate claims center on individual rights by using a corporate form that minimizes individual rights ${ }^{31}$ as a core example of justifiable corporate claims. Thus, each of the Court's arguments for holding that corporations are capable of exercising religion suggests a narrative focused on corporate beliefs and conduct and undermines a narrative focused on individuals.

Third, the Court rejected the argument that its decision would spark unmanageable controversy among owners about the religious claims their corporations would make based on the idea that state law regarding corporate governance would resolve their disputes. ${ }^{32}$ In a narrative focused on corporate rights, this is the correct approach because state law identifies the parties who have legal control over the corporation and can therefore speak on its behalf to identify the religious beliefs that govern its conduct. In a narrative that said corporate claims are vehicles for defending individual rights, this could appear to be a decision permitting state law to determine that some individuals' rights deserve protection while other individuals' rights do not. ${ }^{33}$ In summary, the arguments in Hobby Lobby that corporations are persons, that

\footnotetext{
${ }^{30} I d$. at 2771 .

${ }^{31}$ See Christopher Lacovara, Note, Strange Creatures: A Hybrid Approach to Fiduciary Duty in Benefit Corporations, 2011 CoLUM. BUS. L. REV. 815, 843 (2011) (noting that legislators pass benefit-corporation statutes with the intent of shielding directors from liability to shareholders asserting a right to have their profit maximized). ${ }^{32} I d$. at $2774-75$.

${ }^{33}$ See text accompanying notes 142-44, supra (contrasting liberal, originalist, and hybrid approaches to a dispute among owners in which a majority of owners enjoys control of the corporation under state law but is opposed by a minority).
} 
corporations can exercise religion, and that state law can resolve disputes among owners all suggest a narrative focused on corporations and undermine a narrative focused on individuals.

3. The Rhetoric and Analysis in the Nonprofit Cases Suggest That Corporations Have Legally Cognizable Religious Beliefs

The Supreme Court's decision to treat for-profit corporations like nonprofit corporations for purposes of determining RFRA's reach suggests that the more developed body of precedents surrounding religious liberty claims by nonprofit corporations may provide helpful guidance in resolving the internal tension between Hobby Lobby's rhetoric and its doctrinal analysis. Like the doctrinal analysis in Hobby Lobby, the Supreme Court's treatment of claims by nonprofit corporations suggests a narrative in which the religious beliefs relevant to a corporation's free exercise claim are the corporation's own beliefs, meaning the beliefs that the corporation accepts as governing its conduct.

In 2012, the Court decided Hosanna-Tabor Evangelical Lutheran Church and School v. EEOC.$^{34}$ Hosanna-Tabor was a church congregation that operated a small school and held membership in a Lutheran denomination known as the Missouri Synod. ${ }^{35}$ The church hired "called" teachers, who were commissioned by the church as ministers after a course of religious training. ${ }^{36}$ When called teachers were not available, the church hired "lay" teachers who needed no religious credentials. ${ }^{37}$ The church asked one of its called teachers to step down after she was diagnosed with narcolepsy, was unable to teach for several months, and was replaced by another teacher. ${ }^{38}$ When the teacher declined to step down and threatened to sue the church, the church

\footnotetext{
34132 S.Ct. 694 (2012).

${ }^{35} \mathrm{Id}$. at 699.

${ }^{36} \mathrm{Id}$.

${ }^{37} I d$. at $699-00$.

${ }^{38} \mathrm{Id}$. at 700.
} 
fired her. ${ }^{39}$ The teacher and the EEOC sued the church for discriminating on the basis of disability and for retaliating against the teacher because she sought to prevent discrimination by threatening a lawsuit. ${ }^{40}$ The church argued that its decision to fire the teacher was protected by the religion clauses of the First Amendment as a religiously motivated decision regarding the employment of a minister. ${ }^{41}$ In accepting this position, the Court did not explicitly find any religious beliefs relevant to the church's religious liberty argument.

However, two of the concurring opinions in Hosanna-Tabor did identify religious beliefs as relevant to the church's assertion of a First Amendment right to fire the teacher. In concurring with the judgment of the Court, Justice Thomas relied on the church's belief that called teachers are ministers, writing that the definition of "minister" was a religious question. ${ }^{42}$ Justice Alito, joined by Justice Kagan, wrote that "minister" could be legally defined, but found relevant the church's religious belief that the teacher became unsuited for ministry when she violated the doctrine that disputes among Christians should be resolved within the church ${ }^{43}$ Both concurring opinions stated that the religious beliefs in question were those of the church, a nonprofit corporation. Neither explained why the belief in question could properly be attributed to the corporation.

The Court's 2006 decision in Gonzales v. O Centro Espirita Beneficente Uniao do Vegetal $^{44}$ is similar in treating a corporation as capable of holding and acting according to religious beliefs and in providing no guidance on how the corporation's beliefs were identified. O Centro Espírita Beneficente Uniã do Vegetal (UDV) is a small religious sect whose members

\footnotetext{
${ }^{39} I d$.

${ }^{40} I d$. at 701.

${ }^{41} I d$. at $699-00$.

${ }^{42} I d$. at $710-11$ (Thomas, J., concurring).

${ }^{43}$ Id. at 707-08 (Alito, J., concurring).

${ }^{44} 546$ U.S. 418 (2006).
} 
drink a tea containing a controlled substance during a religious ceremony. ${ }^{45}$ The UDV sued for declaratory and injunctive relief after customs inspectors intercepted a shipment of the tea and threatened to sue the sect, arguing that RFRA barred enforcement of the relevant portion of the Controlled Substances Act. ${ }^{46}$ The Supreme Court affirmed the district court's grant of relief, but shed little light on how it identified the religious belief that was being burdened under RFRA. The Court stated that the corporation's exercise of religion was the relevant religious conduct, but relied entirely on the government's concession that the "challenged application of the Controlled Substances Act would substantially burden a sincere exercise of religion by the UDV."47

The Court's decision in Church of the Lukumi Babalu Aye, Inc. v. City of Hialeah ${ }^{48}$ may provide more insight into how courts identify a corporation's beliefs. In Lukumi, a church organized as a nonprofit corporation followed the Santeria religion's practice of animal sacrifice. ${ }^{49}$ When the City of Hialeah enacted ordinances prohibiting ritual slaughter of animals, the church and its president brought a free exercise claim against the city. ${ }^{50}$ In its recital of facts, the Supreme Court noted that " $[\mathrm{t}]$ he Church and its congregants practice the Santeria religion," that the church's president and priest held high office in the Santeria faith, and that the church's president had stated the organization's goal of bringing Santeria practices into the open. ${ }^{51}$

The facts the Court recited suggest that some of the factors in determining an organization's religion may include its record of religious practice and statements of religious motivation made by its leaders. However, the Supreme Court did not explicitly appeal to any of

\footnotetext{
${ }^{45}$ Id. at 425 .

${ }^{46} I d$. at $425-26$.

${ }^{47} \mathrm{Id}$. at 426.

48508 U.S. 520 (1993).

${ }^{49} I d$. at 525-26.

${ }^{50} \mathrm{Id}$. at 528 .

${ }^{51} I d$. at 525-26.
} 
these factors in its Free Exercise Clause analysis. Rather, the Supreme Court noted the historical association of religious worship with animal sacrifice as support for the proposition that “petitioners' assertion that animal sacrifice is an integral part of their religion 'cannot be deemed bizarre or incredible." ${ }^{52}$ It then relied on the fact that all parties accepted "the sincerity of petitioners' professed desire to conduct animal sacrifices for religious reasons. ${ }^{, 53}$ The Supreme Court's decision that the city ordinances in Lukumi violated the Free Exercise Clause therefore affirmed that the church - a corporation - had a sincere religious belief that formed the basis for its claim. However, it did not make explicit the basis on which it recognized the belief as attributable to the church.

Perhaps because it does not involve a church, Bob Jones Univ. v. United States ${ }^{54}$ includes a somewhat more detailed analysis of how a corporation's religious beliefs may be identified. In Bob Jones, the Supreme Court recognized that conditioning tax-exempt status on nondiscrimination might burden the religious liberty of Bob Jones University and of Goldsboro Christian Schools. ${ }^{55}$ Notwithstanding this burden, the Court held, enforcement of the law was permissible under the Free Exercise Clause because the government had no less restrictive means of furthering its compelling interest in eradicating racial discrimination in education. ${ }^{56}$

The religious beliefs motivating the actions burdened by the law were indicated by several factors. In discussing Goldsboro Christian, the Supreme Court cited the corporation's articles of incorporation to establish religious purpose. ${ }^{57}$ It also referenced the school's practices of beginning classes with prayer, requiring students to take Bible courses, and engaging in

\footnotetext{
${ }^{52} I d$. at 531.

${ }^{53} I d$.

${ }_{55}^{54} 461$ U.S. 574 (1983).

${ }^{55} \mathrm{Id}$. at 604 .

${ }^{56} \mathrm{Id}$.

${ }^{57} I d$. at 604.
} 
racially discriminatory admissions practices "based upon its interpretation of the Bible." ${ }^{, T}$ The Court found this record adequate to support the district court's assumption that the corporation's discriminatory conduct was based on sincere religious beliefs. ${ }^{59}$

In discussing Bob Jones, the Supreme Court again cited the corporation's certificate of incorporation for the proposition that the corporation had a religious purpose. ${ }^{60}$ It also stated that the university's sponsors genuinely believed that interracial dating and marriage were forbidden by the Bible and referenced the school's practices of screening teachers and students for their religious beliefs, teaching classes according to the Bible, and forbidding interracial dating and marriage. ${ }^{61}$ The Supreme Court relied on the district court's finding, based on this record, that Bob Jones University's discriminatory conduct was motivated by a genuine religious belief. ${ }^{62}$ Interestingly, the district court's finding emphasized that Bob Jones University was not an entity affiliated with "a recognized church that may allude in its educational processes to the beliefs of the parent religious order. Instead, the organizational source of plaintiff's religious beliefs is the university." ${ }^{63}$ Bob Jones suggests that an organization - even if it is not a church-may choose its own religious beliefs and indicate them through its articles of incorporation and its pattern of conduct.

The nonprofit cases provide two primary insights that could shape the next chapter in the law of corporate religious liberty. The first insight, on which the nonprofit cases are unanimous, is that the beliefs relevant to a corporation's claims are not the beliefs of any individuals as individuals but the beliefs that courts can attribute to the corporation itself. The second insight is

\footnotetext{
${ }^{58} \mathrm{Id}$.

${ }^{59}$ Id. at 602 n. 28.

${ }^{60} \mathrm{Id}$. at 583.

${ }^{61} I d$.

${ }^{62} \mathrm{Id}$. at 602 n. 28 .

${ }^{63}$ Bob Jones Univ. v. United States, 468 F. Supp. 890, 895 (D.S.C. 1978) rev'd, 639 F.2d 147 (4th Cir. 1980) aff'd, 461 U.S. 574 (1983).
} 
that the Supreme Court seems to view a corporation's statements of religious purpose ${ }^{64}$ and record of religious practice ${ }^{65}$ as indicators of its religious beliefs ${ }^{66}$ It is interesting to note that the Court in Hobby Lobby referred to both corporate statements and corporate conduct in describing the religious beliefs the government had burdened. The pattern in the case law is that these factors indicate corporate belief and justify corporate claims, but the Court's rhetoric in Hobby Lobby strongly suggests a focus on individual beliefs as the core of corporate claims.

\section{B. Ambiguity About Which Individuals'Beliefs Are Relevant}

The arguments presented to, and ultimately embraced by, the Supreme Court in Hobby Lobby identify the beliefs and actions of Hobby Lobby's and Conestoga Wood's owners as the beliefs relevant to the corporations' claims but could, in other cases, serve equally well to justify consideration of the religious beliefs of any other corporate constituency. ${ }^{67}$ In Hobby Lobby, the corporations' owners represented multiple corporate constituencies, and it is unclear on what basis the owner's religious beliefs were considered relevant to the corporate claims. Marty Lederman has argued that the legitimacy of the corporate claims turns on whether the claims were brought to vindicate the rights of the owners as shareholders, as administrators, or as decision makers. ${ }^{68}$ Nor are these the only constituencies whose religious beliefs may be relevant to a corporation's religious liberty claim. It has been suggested that the religiously motivated desires of employees to integrate their faith with their work and of customers to patronize

\footnotetext{
${ }^{64}$ Statements by the corporation's president in Lukumi and statements in the corporations' articles of incorporation in Bob Jones.

${ }^{65}$ Animal sacrifice in Lukumi and racial discrimination in Bob Jones.

${ }^{66}$ In Lukumi and in Bob Jones, the statements of religious purpose pointed toward the same religious beliefs as the records of religious practice. Whether either type of evidence, uncorroborated by the other, could ever be sufficiently strong to support a corporation's claim appears to be a question that has never confronted the Court.

${ }^{67}$ See generally Churchill, supra, note 1.

${ }^{68}$ Marty Lederman, "Hobby Lobby Part V: Whose Religious Exercise? Of corporations, for-profit employers, and individual plaintiffs acting in their various corporate capacities," Balkinization (January 28, 2014), available at http://balkin.blogspot.com/2014/01/hobby-lobby-part-v-whose-religious.html.
} 
religious businesses may play a role in supporting a corporation's claim for an exemption. ${ }^{69}$ Quite aside from the religious beliefs of shareholders, administrators, decision makers, employees, and customers, a corporation's "history, policies, practices, statements and charter could all be examined" as relevant factors in assessing a corporation's claim for a religious exemption. ${ }^{70}$ A well-developed doctrine of sincerity in the corporate context would have to determine which of these considerations are relevant and how they should be weighed in assessing a corporation's claim.

Hobby Lobby suggests that each of these factors could be relevant but contains no developed doctrine of how they should be weighed against each other. Because the arguments presented to the Court focused on the religious beliefs of owners and the facts of the case made it unnecessary to distinguish between the several corporate constituencies that may be represented by owners, it is difficult to generalize from the Court's substantial burden analysis. The Court's standing analysis, however, articulates in broader terms its understanding of how corporations exercise religion and why they should be able to make religious liberty claims. Every step of this analysis permits — and in some cases suggests_that corporations have a right to bring RFRA claims grounded in the religious beliefs of constituencies other than owners because the beliefs of various constituencies may be attributed to corporations. $^{71}$

The implication that corporate RFRA claims need not be based on the religious beliefs of owners is strongest in the Court's argument that for-profit corporations are capable

\footnotetext{
${ }^{69}$ See Ronald J. Colombo, The Naked Private Square, 51 Hous. L. Rev. 1, 66-67 (2013) (arguing that Chick-Fil-A should have standing to claim religious exemptions in part because the operation of the company based on biblical values "is something that customers and employees appear to actively support").

${ }^{70} \mathrm{Id}$. at 64.

${ }^{71}$ See generally Churchill, supra note 1.
} 
of exercising religion. ${ }^{72}$ The Court developed its argument in two stages. First, it stated that the corporate form did not prevent the plaintiffs from exercising religion, citing its decisions recognizing the rights of nonprofit corporations and implicitly holding that for-profit corporations and nonprofit corporations are indistinguishable for purposes of religious exercise ${ }^{73}$ Responding to the dissent's argument that the two corporate forms may be distinguished based on the role that nonprofit standing could play in promoting individual religious freedom, the Court noted that for-profit standing would likewise promote individual religious freedom. ${ }^{74}$ Although, in Hobby Lobby, this reasoning justified a right to make claims related to the religious beliefs of owners, it provides equally strong justification for a right to make claims related to the beliefs of any other constituency.

The second stage of the Court's argument was to show that a profit motive is not exclusive of religious conduct. The Court cited precedents showing that sole proprietors may exercise religion while seeking profit to establish a presumption that monetary and religious motives may coexist. ${ }^{75}$ It then countered the argument that for-profit corporations are an exception to this rule because they are legal entities created solely for the purpose of making money, using three arguments that all suggest a corporation's exercise of religion may be governed by the beliefs of non-owners.

First, the Court rejected the characterization of for-profit corporations as legal entities created solely for seeking profit on the ground that state law authorizes corporations to act for any lawful purpose ${ }^{76}$ For-profit corporations, the Court noted, have as much of a legal right to further religious objectives as to undertake other costly initiatives ranging from pollution

\footnotetext{
${ }^{72}$ The following six paragraphs use analysis drawn from $i d$. at $445-47,449$.

${ }^{73}$ Hobby Lobby, 134 S. Ct. at 2769.

${ }^{74} \mathrm{Id}$.

${ }^{75} I d$. at 2769-70.

${ }^{76} \mathrm{Id}$. at 2770-72.
} 
control and energy conservation to improvements in working conditions and benefits when their owners agree to pursue those ends. ${ }^{77}$ Although the Court only explicitly noted that corporations enjoy the right to pursue religious goals when their owners agree, as they did in the case before it, the agreement of other constituents in other cases may activate the same legal right on which the Court relied. Corporate law recognizes that ownership and management may be separated, and it is possible for a corporation's management to choose a religious objective for the company to pursue without obtaining approval from its owners. ${ }^{78}$ Because the Court's first argument turns on a right of corporations that may be exercised pursuant to the religious beliefs of constituents other than owners, it suggests that owners are not the only individuals whose beliefs may be attributed to a corporation making a religious liberty claim.

Second, the Court rejected the characterization of for-profit corporations as entities that exist solely to make money on the ground that for-profit corporations have been observed to engage in religious and charitable activities that do not maximize profit. ${ }^{79}$ The Court noted that for-profit corporations can pursue religious and charitable aims in ways that nonprofits cannot and quoted Hobby Lobby's statement of purpose and Conestoga Wood's statement of vision and values to demonstrate that for-profit corporations sometimes do "seek to perpetuate the religious values shared, in these cases, by their owners. ${ }^{״ 80}$ The Court's observation that the religious values were, "in these cases," shared by the corporations' owners implies that, in other cases, corporations might seek to perpetuate the religious values shared by other constituencies. This inference not only tracks the Court's language but also

\footnotetext{
${ }^{77} I d$. at 2771.

${ }^{78}$ See Reuven S. Avi-Yonah, The Cyclical Transformations of the Corporate Form: A Historical Perspective on Corporate Social Responsibility, 30 DEL. J. CORP. L. 767, 792 (2005).

${ }^{79}$ Hobby Lobby, 134 S. Ct. at 2770 n.23, 2771.

${ }^{80} \mathrm{Id}$. at 2770 n.23 (internal quotes omitted).
} 
reflects its underlying logic. The Court's argument hinges on the unspoken premise that religious aims in corporate statements of purpose and values may be attributed to corporations. The individuals who own a corporation at the time it makes a claim are not always the authors of these statements and do not necessarily share the religious views of those who framed the statements. Thus, the Court's second argument, like the first, suggests that the religious beliefs underlying a corporation's RFRA claim do not need to be the beliefs of owners.

Third, the Court rejected the characterization of for-profit corporations as entities that exist solely to make money on the ground that states have formally recognized the religious and charitable aims of for-profit corporations by creating the benefit corporation, which seeks a public benefit and a profit at the same time. ${ }^{81}$ One of the key reasons for recognizing these dual purposes is to enable the directors of benefit corporations to make decisions that are not in the best financial interest of shareholders without incurring liability for breach of fiduciary duty. ${ }^{82}$ In a sense, then, the benefit corporation exists to diminish the power of a company's owners to assert a right that should guide the company's decisions. This makes benefit corporations a peculiar example for the Court to use if it intended for owners to be the only constituency whose religious beliefs could control a corporation's acts. The Court implies that the religious purpose stated in a benefit corporation's charter could form the basis of a corporate RFRA claim, despite the possibility that its owners at the time of the lawsuit might not share the religious beliefs the corporation would assert. In summary, each of the Court's arguments against the idea that for-profit corporations exist solely to seek a profit attributes

\footnotetext{
${ }^{81}$ Id. at 2771.

${ }^{82}$ See Christopher Lacovara, Note, Strange Creatures: A Hybrid Approach to Fiduciary Duty in Benefit Corporations, 2011 Colum. Bus. L. REV. 815, 843 (2011) (noting that legislators pass benefit-corporation statutes with the intent of shielding directors from liability to shareholders asserting a right to have their profit maximized).
} 
religious beliefs to corporations on grounds that are not intrinsically tied to ownership.

At the merits stage of its analysis in Hobby Lobby, the Supreme Court treated the religious beliefs of the corporations' owners- the only individual beliefs at issue in the case - as the beliefs behind the corporations' claims. But the Court's standing analysis opens a door for corporations to make claims that are based, not on the religious liberty of their owners, but on the religious beliefs of other constituencies. The possibility of a corporate right to make claims that is distinct from the rights and beliefs of owners raises important questions that Hobby Lobby and the nonprofit cases do not fully answer. At a theoretical level, existing law leaves room for debate about whether corporate standing exists to protect individuals, as Hobby Lobby's rhetoric explicitly states, or to protect corporations, as the analysis in Hobby Lobby and other cases implicitly suggests. At a practical level, existing law provides little direction regarding which individuals' religious beliefs a corporation may claim in seeking an exemption. To answer these questions, the next chapter of the law of corporate religious liberty must interpret the last and seek to develop a coherent narrative about why, when, and how any given individual's belief is relevant to a corporate claim.

\section{The NeXT Chapter IN A Liberal NARRATIVE}

The protagonists in Hobby Lobby, if it tells a liberal narrative, are the Greens and Hahns. At the beginning of this story, the Greens and Hahns live in light of their beliefs and enjoy a sense of wellbeing and fulfillment connected to doing what they feel is right. This includes avoiding culpability for what they view as murder by refraining from helping women obtain drugs that could destroy embryonic life ${ }^{83}$ Then HHS comes along with a laudable policy goal that it unfortunately seeks to promote by regulating corporations in a way that forces the Greens

\footnotetext{
${ }^{83}$ Id. at 1187.
} 
and Hahns to violate their consciences. ${ }^{84}$ Because HHS could have accomplished its goals without forcing the Greens and Hahns to violate their deeply held beliefs if it had cared about their wellbeing and fulfillment, the regulation is unjustified and shows a failure to respect the Greens and Hahns. Under these circumstances, the need for judicial intervention to stop the government from forcing individuals to violate their beliefs justifies courts in recognizing corporate standing. This allows the courts to strike down the unjustified regulation so that the government will pursue its goals in a way that allows the Greens and Hahns to continue experiencing the sense of wellbeing and fulfillment that comes from following the dictates of conscience.

This interpretation of Hobby Lobby seems intuitive and straightforward. It finds support in the rhetoric of Hobby Lobby and is likely to appeal to an individualistic society. However, its individualistic justification for corporate standing provides no principled basis for distinguishing among individuals impacted by a regulation in order to choose which protagonists to protect. The result is an unruly doctrine of balancing individuals' competing interests not only to determine whether an accommodation is feasible but also to determine whether an asserted belief is sincere. The liberal narrative proposes a popular justification of corporate standing that fits Hobby Lobby's rhetoric but uses that justification to build an unmanageable doctrinal test of sincerity that fits poorly with existing law.

\section{A. The Narrative: Corporate Claims Are Justified to Protect Individuals Who Care About Their Religious Beliefs}

In the absence of a well-developed doctrine of corporate free exercise that shows how the beliefs of individuals relate to the claims of corporations, determining what factors are relevant to a corporation's claim and how they should be weighed requires an explanation of why

${ }^{84} 77$ Fed. Reg. 8725 (Feb. 15, 2012). 
corporations should be able to seek religious exemptions in the first place. This question depends, in turn, on why any actor should be able to seek a religious exemption. ${ }^{85}$ In the liberal narrative, the government allows actors to seek religious exemptions in order to respect their dignity by recognizing the importance of their welfare. In the view of Douglas Laycock, for example, religious liberty is justified by the fact that religion is so important to many human beings that attempts to control their religious beliefs and actions threatens their happiness and causes human suffering. ${ }^{86}$ Proper respect for human dignity and concern for human feelings therefore dictate that restraints on religious liberty should be avoided except in matters of great concern for civil government. ${ }^{87}$ In this narrative, the only plausible justification of corporate standing to seek exemptions is that it, like individual standing, can serve to protect the qualified right of individuals to follow their religious beliefs.

One distinguishing characteristic of the liberal account is its focus on whether the exempted actor is religious - that is, whether the exempted actor believes in a manner that that is adequately tied to emotional wellbeing. ${ }^{88}$ It makes no reference to deity and does not discuss the nature of the action in question except to note its importance to the claimant. The liberal account focuses on the religious nature of the actor because it focuses on the relationship between the government and those it governs.

The only actors who could be justified in seeking a religious exemption on this theory are those that the government cannot subject to a challenged regulation without an unacceptable disregard for dignity. Religious exemptions protect only actors with a certain type of dignitythat derived from intensely committed belief — and the nature of the actor seeking an exemption

\footnotetext{
${ }^{85}$ Churchill, supra note 27, at 1173-76.

${ }^{86}$ Douglas Laycock, Religious Liberty as Liberty, 7 J. Contemp. Legal Issues 313, 317-318 (1996).

${ }^{87} \mathrm{Id}$.

${ }^{88}$ Churchill, supra note 27, at 1175.
} 
is therefore central to the question of standing. Only actors whose claims are tied to beliefs held with strong emotional commitment should have standing. Unless it can be shown that a corporation is capable of religious (emotionally intense) belief or that regulation of the corporate is intrinsically tied to human welfare, one is justified in presuming that the corporation has no right to a religious exemption. ${ }^{89}$

Given this presumption, corporations themselves could have a right to religious liberty that justifies their claims only if they are capable of holding religious beliefs - that is, if they are capable of believing in a way that commands respect like that commanded by the beliefs of individual human beings. ${ }^{90}$ An argument that corporations hold beliefs that are religious in this sense seems implausible. ${ }^{91}$ In fact, none of the arguments presented to the Supreme Court in Hobby Lobby were capable of overcoming the liberal presumption that corporations do not have standing as a means of vindicating their own rights. ${ }^{92}$

Nevertheless, the liberal narrative recognizes that individuals have a right to religious liberty and has the potential to justify corporate standing as a means of vindicating their rights. This is the type of justification offered by the arguments presented to the Court in Hobby Lobby that individuals have a right to exercise religion in associations and that forcing a corporation to take an action has the practical result of forcing individuals within the corporation to take that action despite their religious beliefs. ${ }^{93}$ If Hobby Lobby told a liberal narrative, it could not have

${ }^{89}$ Id. at $1174-75$.

${ }^{90} \mathrm{Id}$. at 1186.

${ }^{91}$ Id. (citing Conestoga Wood, 724 F.3d at 385; Hobby Lobby Stores, Inc. v. Sebelius, 723 F.3d 1114, 1169 (10th Cir. 2013) (Briscoe, C.J., concurring in part and dissenting in part) and quoting Citizens United v. Fed. Election Comm'n, 558 U.S. 310, 466 (2010) (Stevens, J., concurring in part and dissenting in part) ("[C]orporations have no consciences, no beliefs, no feelings, no thoughts, no desires.”)).

${ }^{92}$ Churchill, supra note 27 , at 1176-85.

${ }^{93} I d$. at 1187-90. The argument that the differences between nonprofit and for-profit corporations have no bearing on the manner in which they practice religion may be interpreted in a manner consistent with the dignity-centered perspective. If the rights of nonprofits derive from the rights of individuals, the argument would lead to the 
recognized corporate standing to protect corporations but must have recognized it in order to protect the dignity of individuals.

\section{B. The Doctrinal Test of Sincerity: Balancing the Beliefs of Individuals}

The liberal narrative takes a corporation's assertion of religious beliefs as part of the legal fiction of corporate personhood and understands the truly relevant beliefs to be those of individuals. The key problem in translating this understanding into doctrine is that it does not explain how different individual beliefs implicated by government regulation relate to a corporate claim. This problem manifests itself in two ways. First, as the hypotheticals explored in Part V illustrate, it prevents the liberal narrative from recognizing or responding to intuitively recognizable differences in the strength of corporate claims based on the beliefs of different individuals. Second, as discussed in this section, it creates great difficulty for an analysis of corporate claims that impact individuals with conflicting religious beliefs.

Consider the stylized situation in which only two contradictory religious beliefs are implicated by a government regulation, and one religion is subscribed to by a majority of the individuals who are impacted. In the liberal narrative, the purpose of recognizing a corporate claim is to vindicate the religious liberty of individuals. The rights of each impacted individual are relevant to this goal and therefore relevant to the claim. In this scenario, however, vindicating the religious liberty of all the individuals involved is impossible, and the principle of vindicating individual rights gives little guidance for determining whose rights should be preferred.

The liberal narrative cannot justify courts in rejecting corporate claims for lack of unanimity in the beliefs of impacted individuals. Such an evasion of the problem would make the narrative incompatible with existing doctrine because Hobby Lobby implicitly stated unanimity 
is not a prerequisite for standing when it suggested that corporate law should guide courts in determining which beliefs a corporation could claim when its owners disagreed with each other. ${ }^{94}$ Denying standing for lack of unanimity would also be in tension with the liberal narrative's own justification of corporate standing. If the need to respect human dignity justifies corporate claims, corporations should have standing whenever a human's dignity is implicated by a regulation. The fact that other humans' dignity and welfare are also implicated should not weaken and should arguably strengthen the claim for standing. Thus, the liberal is forced to develop a doctrinal test for sorting out which individuals' beliefs a corporation should be able to claim in seeking an exemption.

The liberal might argue that courts should consider the religious beliefs of the majority more relevant to the corporation's claim than the religious beliefs of the minority because the state should seek to maximize the number of people respected by its decisions. This seems like an odd way to treat human dignity, however, especially given the historically countermajoritarian impulse behind religious liberty. An approach that focuses on the net number of people impacted positively by a decision not only favors popular religious views that likely do not need protection from RFRA or the First Amendment, but also has the perverse effect of making controversy over a religious belief (to the extent that it pushes other religions to develop and articulate positions contrary to the controversial position) a reason to afford it less protection.

Even in terms of respecting human welfare and avoiding emotional harm, a majoritarian approach is only justified as the approach that maximizes respect for dignity if all individuals have an equal interest in a requested exemption—or, in more familiar legal terms, if each individual is equally burdened by the regulation. It seems clear, however, that different

\footnotetext{
${ }^{94}$ Hobby Lobby, 134 S. Ct. at 2775.
} 
individuals suffer different degrees of emotional injury depending on how they are situated relative to a corporation. The majoritarian approach would treat the religious beliefs of a man who founds a corporation and retains hundreds of shares but gives a share to each of his two children as no more important to the company's claim than the beliefs of the children. It would treat the religious beliefs of a church's leaders and congregants as no more important to its claims than the beliefs of clients it engages through the school it runs. ${ }^{95}$ Treating all individuals as having an equal interest in the outcome of a religious liberty claim leads to outcomes that cause more emotional harm than necessary, contrary to the policy of recognizing corporate standing in order to avoid emotional harm and promote human welfare.

A truly dignity-driven approach to conflicts among those whose religious beliefs are implicated by a corporation's claim would involve a utilitarian-type analysis that would weigh the interests of each affected individual. Utilitarian analyses of this type are notoriously difficult to conduct, however. Proper weighing of interests would account not only for the different ways in which differently situated individuals are impacted by government regulation, but also for the relative respect commanded by each individual's belief (that is, the relative intensity with which each individual believes). In an ideal world, then, the liberal narrative would call for an approach to conflicts among owners that involves courts in the inappropriate task of comparing the dignity of different individuals and their beliefs.

\footnotetext{
${ }^{95}$ This leads to curious results if the church has more clients through the school than it has congregants. If this had been the situation in Hosanna-Tabor and the church had sought an exemption from an anti-discrimination law in order to allow disciplinary action against a pastor pursuant to Lutheran doctrine, the beliefs of the clients would not be implicated and the religious beliefs relevant to the claim would be those of the church's leaders and members. If this same church had at the same time sought an exemption from the same law in order to allow disciplinary action against a "called" teacher, the clients of the church's school would be impacted by the claim. If a large enough number of clients had a religious belief that the school they attended should not practice discrimination, their religious belief would be considered more important in assessing the church's claim than the beliefs of the church's leaders and congregants. A court would be required to view the Lutheran church's first claim as an effort to vindicate the religious liberty of Lutherans and to reject the Lutheran church's second claim because the church should only have had standing to vindicate the religious liberty of those seeking to prevent Lutherans from acting according to their religious beliefs.
} 
Because this task is inappropriate to the judiciary, however, a liberal in the real world might call for a next-best approximation of the utilitarian analysis described above. Although courts may not inquire into the relative dignity of different individual's beliefs, they may at least attempt to account for the different ways in which different actors are situated. This approach would be difficult to defend in cases where a small number of individuals are involved, but may be justified when there are a large number of individuals on each side of a question. If it is assumed that variations in dignity (intensity) of belief will cancel each other out in large groups so that the average intensity per person in any two groups of adequate size will be the same, there may be no need to consider factors other than the number of actors involved and the ways in which they are impacted. The liberal approach is unable to resolve conflicts among stakeholders where few individuals are involved and such averaging of intensity is unlikely. Nevertheless, it arguably justifies a doctrine applicable to cases that involve many individuals on each side of a question: The religious beliefs that a corporate claim may vindicate are the beliefs of the group of individuals that has the greatest cumulative interest at stake, calculated as a function of the group's size and the position in which the group is situated.

\section{The Fit With Current Doctrine: Strong on Rhetoric, Weak on Substance}

The liberal narrative about corporate religious liberty claims fits well with the statement in Hobby Lobby that RFRA “provided protection for people like the Hahns and Greens" by employing the fiction of corporate personhood and that this fiction should be understood in light of the fact that its purpose is "to provide protection for human beings." 96 It fits with other language in the Hobby Lobby opinion, as described in Part I.A. But the justification of corporate

\footnotetext{
${ }^{96}$ Hobby Lobby, 134 S.Ct. at 2768.
} 
standing offered by the liberal narrative and suggested by these statements is in tension with the Court's substantive analysis in Hobby Lobby and in the nonprofit cases.

Existing law undermines the liberal narrative in several ways. First, it provides no example of courts employing the type of interest balancing doctrine that the liberal narrative suggests. Second, it shows that courts do look to corporate statements and practices in evaluating corporate claims, even though they could be economically rather than religiously motivated and are, at best, only indirect evidence of individual beliefs. ${ }^{97}$ Third, Hobby Lobby's doctrinal argument for corporate standing implicitly rejects the liberal presumption that a nonhuman actor is incapable of religious belief and explicitly states, contrary to the liberal, that corporations are capable of religious conduct. ${ }^{98}$ Fourth, Hobby Lobby pointed to benefit corporations, which minimize the individual rights at the heart of the liberal narrative, as an example of corporations capable of exercising religion. ${ }^{99}$ Fifth, Hobby Lobby pointed to state law as a valid guide to judicial determinations of which individuals' beliefs a corporation could vindicate although this would, from a liberal perspective, be tantamount to an affirmation that state law could determine which individuals should enjoy federal constitutional rights. The intuitive justification of corporate standing offered by the liberal narrative fits well with the rhetoric of Hobby Lobby but is in tension with much of the law.

\section{THE NEXT CHAPTER IN AN ORIGINALIST NARRATIVE}

The protagonists in Hobby Lobby, if it tells an originalist narrative, are the corporate claimants. ${ }^{100}$ At the beginning of the story, the corporations carry on their business and try to

\footnotetext{
${ }_{97}^{97}$ See text accompanying notes 50-67, supra.

${ }^{98}$ See text accompanying notes 24-30, supra.

${ }^{99}$ See text accompanying notes 31-32, supra.

${ }^{100}$ See Churchill, supra note 27, at 1173-76.
} 
obey the dictates of religion and of the state. Then HHS comes along with a laudable policy goal that it unfortunately seeks to promote by regulating the corporations in a way that makes it impossible for them to follow both the law of the state and the command of religion. Because HHS could have accomplished its goals without forcing the corporations to choose between civil and divine authority, the regulation is unjustified and shows a willingness to flout religion. Under these circumstances, the need for judicial intervention to stop the government from needlessly setting itself against and above religious authority justifies courts in recognizing corporate standing. This allows courts to strike down the unjustified regulation and eliminate the conflict between the corporation's civil and religious authorities.

This narrative fits the rhetoric of the nonprofit cases and is intuitive at least insofar as it, unlike the liberal narrative, ties the religious liberty claim to the claimant's religious beliefs and practices. However, this strength is also a weakness. It raises challenging questions about how a court can determine the sincerity of a claimant's religious belief when that claimant is a corporation and not an individual. The narrative's focus on conflicting authorities makes it possible to think of religious beliefs in terms of religious rules of conduct that corporations accept as authoritative without requiring courts to posit that corporations themselves have any strong feelings about the beliefs. The result is a nuanced doctrine that accounts for statements made on behalf of the corporation and for the corporation's record of conduct, mirroring the analysis in Hobby Lobby and the nonprofit cases. The originalist narrative fits well with existing law but proposes a justification of corporate standing that requires courts to treat corporations as having religious beliefs - a position that forces it to rely on a specialized definition of religious belief that some may fail to grasp and with which others may disagree. 


\section{A. The Narrative: Corporate Claims Are Justified to Protect Corporations That Are Under Religious Obligations}

The originalist narrative about religious exemptions, as described by Michael

McConnell, ${ }^{101}$ shifts the focus away from individual feelings and toward religious duties. ${ }^{102}$

Borrowing language from the Virginia Bill of Rights, which reflected at least one understanding of religious liberty current during the First Amendment's drafting, it posits that religion is "the duty which we owe to our Creator, and the manner of discharging it." ${ }^{\prime 103}$ If the state recognizes the possibility that such duties may exist, it will understand conflicts between the dictates of religion and the dictates of the state "not as a clash between the judgment of the individual and of the state, but as a conflict between earthly and spiritual sovereigns." ${ }^{104}$ Religious exemptions, then, are the means by which a state avoids such conflict. Working from these definitions of religion and of religious exemptions, the originalist narrative justifies religious exemptions as a means by which the state may avoid asserting its authority against that of a deity. ${ }^{105}$

One distinguishing characteristic of this narrative is its focus on whether the exempted action is religious - that is, whether the exempted action is related to a duty imposed by a

${ }^{101}$ See Michael W. McConnell, The Origins and Historical Understanding of Free Exercise of Religion, 103 Harv. L. Rev. 1409 (1990). Philip A. Hamburger, A Constitutional Right of Religious Exemption: An Historical Perspective, 60 Geo. Wash. L. Rev. 915 (1992) questions whether McConnell is correct in arguing that the Free Exercise Clause was originally intended to compel religious exemptions but does not dispute more broadly the idea that religious exemptions may be justified on the basis of duty as McConnell suggests.

${ }^{102} I d$. at 22-24.

${ }^{103}$ See McConnell, supra note 101, at 1458 n.242 (quoting Va. Bill of Rights of 1776, § 16, reprinted in 2 FEDERAL and State Constitutions, Colonial Charters, and Other Organic Laws of the United States 1328, 1908-09 (B. POORE 2D ED. 1878).

${ }^{104} \mathrm{Id}$. at 1496.

${ }^{105}$ The value of avoiding such an assertion of authority may be understood in different ways. For example, it may be understood religiously (one may take the position that such an assertion of authority is inappropriate because God's authority exceeds that of the state, see, e.g., Acts 5:29), legally (one may take the position that such an assertion of authority is contrary to the rules posited in the First Amendment or in RFRA, see, generally, McConnell, supra note 101), pragmatically (one may take the position that recognizing the possibility of an authority outside the state "makes an important statement about the limited nature of governmental authority," see, e.g., id. at 1516-17), or even agnostically (one may take the position the state should try to avoid the risk of countermanding what could be a higher authority because it cannot rule out the possibility). 
deity. ${ }^{106}$ Unlike the liberal narrative, it makes no reference to the actor except to note that religious exemptions have nothing to do with a conflict of judgment between the state and the party seeking exemption. The originalist narrative focuses on the religious nature of the action exempted from regulation, and determines its religious nature by asking whether the action is dictated by a deity. Ultimately, this narrative focuses on actions because it focuses on the relationship between civil and spiritual authority.

The relationship between civil authority and spiritual authority is implicated in the same way every time that the two authorities place conflicting duties on an actor. In principle, then, any actor that could be subject to duties imposed by the state and to duties imposed by a deity could be justified in seeking a religious exemption. Religious exemptions protect religious actions, and the nature of the actor seeking a religious exemption is relevant to standing only if it makes the claimant inherently incapable of exercising religion — that is, inherently incapable of being subject to duties imposed by a deity. ${ }^{107}$ Until such a showing can be made, one is justified in presuming that an actor has a right to religious liberty. ${ }^{108}$

Given this presumption, an analysis of whether for-profit corporations should be categorically barred from making religious liberty claims as the government suggested in Hobby Lobby is straightforward. The originalist believes that corporate standing allows corporations to defend their own religious liberty—-their ability to act according to the duties imposed by God. The arguments presented to the Court in Hobby Lobby that RFRA and the First Amendment make no distinction between the rights of corporations and the rights of other actors, that the Free Exercise Clause should protect for-profit corporations if it protects nonprofits and profitseeking individuals, and that state law recognizes for-profit corporations as persons with a right

\footnotetext{
${ }^{106}$ Churchill, supra note 27, at 1174-75.

${ }^{107}$ Id. at 1173 .

${ }^{108} I d$. at 1175.
} 
to pursue any lawful end all rely on the presumption that every actor has free exercise rights unless it can be proven that the actor is incapable of being subjected to duties by God. ${ }^{109}$ Because it is unlikely that the Supreme Court would accept an argument that it is impossible for God to place duties on for-profit corporations, its conclusion that for-profit corporations have standing seems natural. ${ }^{110}$ Because the existence of a duty imposed by God determines whether an action is religious and potentially deserving of exemption, the identity of the claimant is irrelevant to the claim and categorical bars based on the claimant's identity as a corporation are unjustified.

In addition to allowing corporations to defend their own religious liberty, corporate claims may also have the result of protecting the religious liberty of individuals. In the originalist narrative, this benefit is not necessary to justify corporate claims. However, individual religious liberty could be an independently adequate justification of corporate claims because, regardless of whether the rights of corporations or individuals are at stake, corporate exemptions could serve to avoid conflict between God and the state. ${ }^{111}$ Although corporate standing could be justified without appeal to individual rights and individual rights could be vindicated by individual claims, ${ }^{112}$ the originalist narrative could justify corporate standing either as a means of vindicating corporate rights or as a means of vindicating individual rights.

\section{B. The Doctrinal Test of Sincerity: Identifying the Beliefs of Corporations}

The originalist narrative takes a corporation's assertion of religious beliefs as a claim to be governed by religious teachings rather than as part of a legal fiction justified by the importance of individual human feelings. It can therefore avoid the liberal's challenge of

\footnotetext{
${ }^{109} I d$. at $1176-85$.

${ }^{110} \mathrm{Id}$. at $1185-86$.

${ }^{111} \mathrm{Id}$. at $1187-92$.

${ }^{112}$ For an example of this approach, see Gilardi v. Dep't. of Health \& Human Servs., 733 F.3d 1208, $1214-16$ (D.C. Cir. 2013).
} 
fashioning a doctrine by which courts can weigh the relative importance of different individuals' feelings. But the originalist narrative faces its own challenge: It must provide courts with a doctrine that allows them to identify a corporation's religious beliefs. From a liberal perspective, it is not even possible for corporations to have religious beliefs. But because belief plays a different role in the originalist narrative than in the liberal narrative, the originalist can employ a specialized definition of belief that makes corporate religious belief a possibility. ${ }^{113}$

There are two issues to which belief may be relevant in assessing a religious liberty claim: standing and the merits. In the liberal narrative, beliefs justify standing. As a source of rights and a justification for considering an exemption, belief must be understood to mean a conviction held in a way that demands respect. In Laycock's account, religious beliefs are tied to feelings, hurt feelings are a harm that can justify exemptions, and a religious belief must therefore be defined as a conviction to which the believer is emotionally committed.

In the originalist narrative, beliefs explain the content of a claim so it can be assessed on its merits. Standing is justified, in theory, simply by the existence of duties imposed by God that are contrary to those imposed by the state. But because God is not a member of the judiciary, a decision on the merits requires an appeal to some belief about the duties God imposes on an actor. The beliefs to which judges appeal in reaching the merits of a claim are the beliefs of the actors seeking to have their religious action exempted from regulation because the state takes each actor's religious beliefs, rather than any set of beliefs imposed by force, as the proper guide to the discharge of duties owed to God. ${ }^{114}$ Because belief acts as a clarification of what exemption is sought rather than as a source of rights, belief need only define the duties that a

\footnotetext{
${ }^{113}$ Churchill, supra note 27, at 1187 n.59.

${ }^{114}$ See McConnell, supra note 101, at 1458 n.242 (quoting Va. Bill of Rights of 1776, $\S 16$, reprinted in 2 FEDERAL and State Constitutions, Colonial Charters, And Other Organic Laws of the United States 1328, 1908-09 (B. POORE 2D ED. 1878).
} 
deity may be imposing on the actor. Rather than defining religious belief as a claimant's intense conviction, therefore, one may define religious belief as a claimant's acceptance of religious commands as divinely appointed and authoritative guides to action.

Confusion over the idea that corporations may have religious beliefs likely stems from a failure to understand that, although the liberal narrative requires an understanding of belief as involving an intense emotional commitment, the originalist narrative requires only that belief mean the actor's acceptance of a religious duty as its authoritative guide to action. There are at least two types of evidence that may indicate such acceptance of religious duty-statements about the beliefs that govern the corporation and observations of the corporation's actual conduct. There are three basic approaches that courts could take to these sources of evidence.

A legal control approach would focus on statements made about the corporation's belief or, more precisely, statements made on behalf of the corporation by those who exercise control over its conduct. Courts could hold that a religious belief is an authoritative guide to a corporation's conduct in a legally cognizable sense only if a decision maker with legal control over the corporation's conduct states that the belief guides the corporation. This seems to miss key theoretical and practical points, however. The theoretical flaw is a failure to recognize that the originalist narrative dictates an inquiry not into what human decisions the law will recognize as controlling within the governance structure of a corporation but into what duties the corporation believes God has imposed from outside the legal system. One practical concern is that the rule may be under-inclusive with respect to corporations that, for example, provide kosher food to religious customers but happen not to be controlled by religious individuals. Another practical concern is that it seems entirely possible that the policies formally promulgated by those with legal authority over a corporation may have nothing to do with its actual practices, 
so that the approach focused on legal control is over-inclusive and creates a high risk of fraudulent claims.

An apparent control approach reacts to these concerns by focusing on a corporation's record of actual conduct. Courts could hold that a corporation accepts a religious belief as the authoritative guide to its conduct if it actually acts in accordance with the belief. Yet this approach seems to miss two practical points. First, it is entirely possible to hold a sincere religious belief and fail to live up to the duties with which one believes one ought to comply. ${ }^{115}$ In this respect, an approach centered on apparent control may be under-inclusive, allowing religious liberty only for those who consistently succeed in living up to their own principles. This concern may be mitigated, however, by adjusting the strength of the pattern of religious conduct required. Second, and more importantly, it is entirely possible to outwardly comply with a belief that one does not hold. ${ }^{116}$ Third, such an approach would make it impossible to assess the religious beliefs of a new corporation. Thus, the apparent control approach is over-inclusive in some respects and under-inclusive in others, involving a high risk of accepting fraudulent claims and of dismissing legitimate claims.

An actual control approach, a hybrid of the approaches above, allows case-specific balancing of the concerns for over- and under-inclusiveness described above. Courts could recognize statements about the religious beliefs that should guide a company's action as claims that the corporation holds religious beliefs if made by those who exercise control over it ${ }^{117}$ and

\footnotetext{
115 See, e.g., Romans 7:19 ("I do not do the good I want, but the evil I do not want is what I keep on doing.").

${ }^{116}$ See, e.g., 2 Kings 5:18 ("[W] [Wen my master goes into the house of Rimmon to worship there, leaning on my arm, and I bow myself in the house of Rimmon, when I bow myself in the house of Rimmon, the Lord pardon your servant in this matter.").

117 There is room for debate within the originalist framework about whether control must be recognized only when an individual's beliefs are legally binding on the company or may also be recognized as controlling when the individual's beliefs influence those who exercise legal control, as in the case of a single director to whose strong religious beliefs the other directors defer. The reasons discussed above for rejecting the legal control approach to evidence apply with equal force as a reason for rejecting a legal control approach here.
} 
could at the same time recognize the company's actual practices as evidence of sincerity. By recognizing multiple sources of evidence as relevant but distinct, courts could develop a nuanced approach to corporate religious liberty claims. The key question to keep in mind is whether these sources of evidence, taken together, adequately support the corporation's claim that it accepts the religious beliefs in question as authoritative guides to its conduct.

When an individual or coalition of individuals with control over a corporation's conduct asserts during litigation that the corporation has an obligation to act in accordance with a religious belief, the individual is making an assertion on behalf of the corporation, identifying the religious beliefs that may be attributed to it. In the case of an individual or coalition that exercises exclusive legal control over the relevant conduct and has a sincere religious belief that the corporation should be bound by the doctrines in question, the claim to speak on the corporation's behalf by identifying the religious beliefs that authoritatively control its conduct is presumably correct. Nevertheless, evidence that the corporation has not in fact sought to fulfill the religious duties it claims to accept as authoritative may overcome this presumption by showing a lack of sincerity on the corporation's part (showing that the corporation does not in fact accept the religious beliefs in question as authoritative). When the individual's claim to speak for the corporation is strong because the individual exercises legal control over the relevant conduct, there is a rebuttable presumption that the individual's religious beliefs are attributable to the corporation.

In the case of an individual or coalition of individuals that lacks legal control over the corporation but influences its conduct either by exercising a share of legal control or through extralegal means, the claim to identify religious beliefs that are binding on the corporation's conduct is weak. Nevertheless, evidence that the corporation has consistently sought to fulfill the 
religious duties in question could validate the claim, showing that the corporation has in fact sincerely accepted the individual's beliefs as authoritative guides to its conduct. When individuals with shared authority or influence hold competing religious views, the same evidence of actual conduct will show which set of beliefs, if any, really govern the corporation. Thus, when the claim that an individual speaks for the corporation is weak, its sincerity requires supporting evidence from the corporation's record of conduct.

There are two situations in which it cannot be claimed that the individual or coalition speaks for the corporation in identifying its religious duties. First, the individual may have no influence over the corporation. In such a case, the individual's religious belief that the corporation ought to comply with certain doctrines is not a belief controls the corporation's conduct. Second, the individual may not personally hold the religious belief he or she claims should govern the corporation. In such a case, the belief cannot be viewed as authoritative in the sense relevant to the originalist narrative - the belief has not been recognized as a duty imposed by a deity. In either case, the corporation cannot claim that the individual speaks for it in identifying its religious duties. And without an assertion of religious belief made on behalf of the corporation, no amount of evidence from actual practice — which may be coincidental—can establish the corporate belief. ${ }^{118}$ While this rule may seem harsh at first, it seems unlikely to preclude any sincere claims given the breadth of the rule permitting those with extralegal influence over a corporation to speak on its behalf and identify its beliefs.

Each of the situations above may be situated on a sliding scale in which the credibility of a corporation's assertion of religious belief varies inversely with the strength of extrinsic evidence demonstrating sincerity. The scale ranges from situations in which the claim is so

\footnotetext{
${ }^{118}$ Cite HLA Hart's Concept of Law, p. 55-56 (distinguishing behavior, as the external aspect of a rule's acceptance, from a view that a standard requires that behavior, as the internal aspect of a rule).
} 
plausible that no extrinsic evidence is required to situations in which the claim is so implausible that no extrinsic evidence could justify a finding of sincere religious belief. As the analyses above demonstrate, three doctrinal rules can be articulated to specify the way in which this sliding-scale principle applies in different situations:

1. A corporation's claim that it holds the religious beliefs of those who exercise legal control over it is presumed to be an accurate indicator of the religious beliefs that it accepts as authoritative guides to conduct, but this presumption may be overcome by evidence of insincerity demonstrating that the company does not in fact follow the beliefs in question.

2. A corporation's claim that it holds the religious beliefs of those who exercise influence but lack legal control over it is an unreliable indicator of the religious beliefs that it accepts as authoritative guides to conduct, but may be validated by evidence of sincerity demonstrating that the company does in fact follow the beliefs in question.

3. No record of potentially coincidental or strategic compliance with a religious belief can establish a corporation's religious belief absent a corporation's claim that it holds the religious beliefs of those who exercise legal control or recognizable influence over it.

These rules are the originalist's guide to evaluating whether a corporation adopts any individual's beliefs as its own - that is, whether a corporation accepts a particular belief as an authoritative guide to its conduct.

\section{The Fit With Current Doctrine: Weak on Rhetoric, Strong on Substance}

The originalist narrative is in tension with the rhetoric of Hobby Lobby about individual rights lying at the core of corporate claims. The strongest argument against it based on existing law is that Hobby Lobby read RFRA as a congressional effort to use the fiction of corporate personhood "to provide protection for human beings." 119 This reading undermines the originalist argument that corporate claims can be justified without reference to individual feelings. Although the originalist has some grounds for arguing that Hobby Lobby's statement about protecting human beings is dicta and could acknowledge that the beliefs attributed to a

\footnotetext{
${ }^{119}$ Hobby Lobby, 134 S.Ct. at 2768.
} 
corporation are always shared by some individual who influences the corporation's conduct, ${ }^{120}$ it is undeniable that the originalist narrative fits poorly with the rhetoric of Hobby Lobby-rhetoric that may well reflect public suspicion of a narrative that attributes religious beliefs to corporations instead of focusing on individual rights.

On the other hand, the originalist narrative fits well with other aspects of existing law. Several of the arguments for corporate standing in Hobby Lobby employed the originalist presumption in favor of standing, ${ }^{121}$ and one argument pointed to structures that minimize individual rights as examples of corporations that could exercise religion. ${ }^{122}$ The law's approach to recognizing a corporation's religious identity also fits well with the doctrine of sincerity supported by the originalist narrative. Hobby Lobby and the nonprofit cases both noted corporate statements and practices in determining that corporations were religious, as the originalist doctrine of sincerity suggests courts should. Further, Hobby Lobby's suggestion that state law governing corporate decision making structures should resolve conflicts over a corporation's religious identity seems inexplicable from a liberal perspective but tracks well with the originalist understanding that a corporation should only be allowed to claim the beliefs that govern its conduct. ${ }^{123}$ Although the originalist narrative's unintuitive justification of corporate standing fits poorly with the rhetoric of Hobby Lobby, it provides a logical foundation on which to build a doctrine of nuanced doctrine of sincerity that would explain existing law.

\section{The NeXt Chapter in Justice Kennedy’s Hybrid NARRAtive}

\footnotetext{
${ }^{120}$ See text accompanying notes 22-23, supra.

${ }^{121}$ See text accompanying notes 24-30, supra.

122 See text accompanying notes $31-32$, supra.

${ }^{123}$ See text accompanying notes 33-34, supra.
} 
The protagonists in Hobby Lobby, if it tells the hybrid narrative suggested by Justice Kennedy's concurrence, are the Greens and Hahns. At the beginning of the story, they enjoy a sense of wellbeing and fulfillment as they obey their religion's direction to influence the way in which their corporations carry on their business. Then HHS comes along with a laudable policy goal that it unfortunately tries to promote by regulating the corporations in a way that prevents the Greens and Hahns from continuing to influence their corporations in the way their religion requires. Because HHS could have accomplished its goals without forcing the Greens and Hahns to choose between civil and divine authority, the regulation is unjustified and shows both an inadequate concern for human welfare and a willingness to flout religious authority. Under these circumstances, the need for judicial intervention to stop the government from disregarding religious authority and individual wellbeing justifies courts in recognizing corporate standing. This allows courts to strike down the unjustified regulation, promoting the wellbeing and fulfillment of the Greens and Hahns by eliminating the conflict between their civil and religious authorities.

This narrative justifies corporate standing in a way that fits the rhetoric of Hobby Lobby and the analysis in both Hobby Lobby and the nonprofit cases. This justification resonates with both the liberal concern about individual wellbeing and the originalist concern about religious authority. Because the narrative focuses on a specific type of individual wellbeing - that derived from seeking to influence a corporation in accordance with the dictates of one's religion-it provides courts a principled basis for distinguishing between individuals whose religious beliefs actually would guide a corporation's beliefs in the absence of government regulation from individuals whose attempts to influence the corporation would fail regardless of the law. The result is a doctrinal approach to corporate statements and conduct that parallels the one supported 
by the originalist narrative. The hybrid narrative offers a justification of corporate claims that both liberals and originalists will recognize as valid while advancing a doctrine of sincerity that fits existing law.

\section{A. The Narrative: Corporate Claims Are Justified to Protect the Right of Individuals Involved With Corporations to Strive to Follow Their Religious Beliefs}

Justice Kennedy's concurrence in Hobby Lobby suggests a third, hybrid paradigm that may avoid the challenges confronting liberals and originalists. Like liberals, Justice Kennedy bases the claim to a religious exemption on concern for individual human dignity rather than on corporate religious duties. ${ }^{124}$ For religious individuals, Justice Kennedy writes, "free exercise is essential in preserving their own dignity. ${ }^{125}$ Yet he defines this dignity in terms of religious duty, associating it with religious individuals" "striving for a self-definition shaped by their religious precepts" and exercising "the right to believe or strive to believe in a divine creator and a divine law." ${ }^{2126}$ Significantly, this dignity is not dependent on the success of efforts at selfdefinition and belief, but derives from striving for what religion requires. Because failure does not undermine this dignity, Justice Kennedy can marry the liberal's intuitive focus on individual dignity with the originalist insight that free exercise is a negative right against government contradiction of religious mandates rather than an affirmative right to obtain judicial aid against all indignity, including interference with religious practice by other corporate constituencies. ${ }^{127}$

\footnotetext{
${ }^{124}$ Justice Kennedy implied that the plaintiffs whose religious liberty was burdened were individual employers when he wrote "The means the Government chose is the imposition of a direct mandate on the employers in these cases." Burwell v. Hobby Lobby Stores, 134 S. Ct. 2751, 2786 (2014) (Kennedy, J., concurring). He nowhere suggested that the plaintiffs were corporations - the only time he mentioned the existence of Hobby Lobby, he implicitly distinguished it from the plaintiffs by describing the corporation as belonging to the plaintiffs. Id. at 2785 . ${ }^{125}$ Id. at 2785 . 
This narrative is liberal in the sense that it requires an individuals' dignitary interest to justify corporate standing. As in the liberal narrative, the protagonist is the individual and the drama arises out of a threat to the individual's sense of wellbeing and fulfillment. A liberal might criticize the hybrid narrative's justification of corporate standing for recognizing only one way in which regulations of corporations can implicate human dignity. From a perspective focused on the wellbeing and fulfillment of individuals, the fact that an individual is barred from acting in accordance with his religion is adequate basis for standing regardless of whether or not the religious act in question is influencing a corporation's conduct. But even if liberals would recognize additional justifications of corporate standing, they will acknowledge that the hybrid justification is valid because it is based on concern for individual dignity and welfare.

At the same time, the hybrid narrative is originalist in the sense that it relies on a conflict of civil and spiritual authorities to justify corporate standing. As in the originalist narrative, the drama arises out of government interference with efforts to discharge religious duties. An originalist might criticize the hybrid narrative's justification of corporate standing for recognizing only one type of religious duty in the corporate context. From a perspective focused on respecting religious authority, the fact that the state is interfering with religious obligations is adequate basis for standing regardless of whether the obligation applies to an individual seeking to influence a corporation's conduct or to the corporation itself. But even if originalists would recognize additional justifications of corporate standing, they will acknowledge that the hybrid justification is valid because it is based on concern for attempts by the state to countermand religious authorities.

B. The Doctrinal Test of Sincerity: Understanding the Nexus of Individual Beliefs and Corporate Decisions 
The state's concern about needlessly countermanding religious authority leads to an individual right against the government erecting unnecessary obstacles to the exercise of religion, but does not entitle individuals to seek the government's aid in removing obstacles unrelated to government conduct. Therefore, the hybrid narrative asks courts to evaluate whether government action is responsible for an individual's inability to influence corporate conduct in accordance with the dictates of his or her religion. In determining whose religious beliefs a corporate claim may vindicate, courts have a principled basis for distinguishing between individuals with influence over corporate conduct and other individuals whose beliefs are irrelevant to the corporate claim. This basis for distinguishing among individuals allows the narrative to focus on individuals without facing the liberal challenge of balancing competing dignitary interests. In fact, the question the hybrid narrative presents to courts suggests a doctrinal analysis that matches the one suggested by the originalist narrative.

The question in a hybrid narrative is whether government conduct is responsible for thwarting individual efforts to follow religious duties by influencing corporate conduct. In answering this question, courts would naturally look to whether the individuals had religious ideas about corporate conduct and to the extent of their influence over the corporation. For a corporate claim to vindicate an individual's religious liberty against the government, the individual must have religious beliefs about how the corporation should act and the individual must have legal control or functional influence over corporate conduct.

Individuals who state that they have religious beliefs about how the corporation should act and who exercise legal control over corporate conduct would justify standing unless the corporation's record showed that it did not follow the asserted religious duty. Individuals who state that they have religious beliefs about how the corporation should act and who exercise 
actual control over corporate conduct would also justify standing. The test should be one of actual control rather than legal control or apparent control for substantially the same reasons discussed in Part III.B, and could be articulated in three rules that parallel those advocated by the originalist:

1. A corporation's claim can be based on the religious beliefs of those who exercise legal control over it unless the company's record of conduct undermines the sincerity of the claim by showing that the company does not in fact follow the beliefs in question.

2. A corporation's claim can be based on the religious beliefs of those who exercise influence but lack legal control over it only if the company's record of conduct validates the sincerity of the claim by showing that the company does in fact follow the beliefs in question.

3. A corporation's claim cannot be based on a record of potentially coincidental or strategic compliance with a religious belief not held by an individual who exercises legal control or recognizable influence over the relevant corporate conduct.

Although these doctrinal rules would not employ the same rhetoric of corporate belief as their originalist counterparts, their substance is nearly the same. ${ }^{128}$

\section{The Fit With Current Doctrine: Strong on Rhetoric and on Substance}

The hybrid narrative fits the rhetoric of Hobby Lobby about corporate standing serving as a vehicle to protect individual rights and helps to resolve some of the tension between this language and other parts of the Supreme Court's jurisprudence. The Court's references to state corporate law, including the founder-favoring authority structure of benefit corporations, flow from the fact that legal control over corporate conduct strengthens an individual's argument that his or her beliefs are relevant to a corporation's claim in a hybrid narrative. The Court's attention to corporate statements and corporate records of conduct fits the hybrid narrative's actual control test. Because it focuses on individuals but limiting the relevant inquiry to the beliefs of only

\footnotetext{
${ }^{128}$ For one situation in which the originalist and hybrid approaches would differ, see text accompanying notes $137-$ 41, infra.
} 
those individuals who control a corporation's conduct, the hybrid narrative reconciles features of the law that liberals and originalists see in tension, providing the best fit with existing doctrine.

\section{The Originalist And Hybrid Doctrines of Corporate Sincerity Are More MANAGEABLE THAN THE LIBERAL BALANCING DOCTRINE}

This section uses a series of hypotheticals to explore the practical differences between the balancing doctrine supported by the liberal narrative and the rule-based doctrine of corporate sincerity supported by the originalist and hybrid narratives. It explores in turn the relevance of the beliefs of a corporation's owners, directors and managers, employees, customers, and founders to a religious liberty claim made by the corporation. It shows that the liberal narrative is unable to support intuitive distinctions explained by the originalist and hybrid narratives. It also shows that the liberal analysis is often unable to provide guidance in situations of conflict among those impacted by a government regulation, whereas the situations are easy to assess under the rule-based doctrine of sincerity.

\section{A. The Relevance of the Beliefs of Owners}

Four hypotheticals help illustrate the contrast between the balancing and rule-based approaches to determining how the beliefs of owners relate to a corporation's claim. Each is a particular instantiation of the possibility, raised in Justice Ginsburg's Hobby Lobby dissent, that a corporation's owners may not share a common faith. ${ }^{129}$ These scenarios are difficult to distinguish from a liberal perspective, but may be evaluated in a more nuanced manner using a rule-based doctrine.

First, consider a corporation seeking an exemption that would enable it to act in a way that a majority of its owners desire for religious reasons, although a minority of its owners object

\footnotetext{
${ }^{129}$ Hobby Lobby, 134 S. Ct. at 2797 (Ginsburg, J., dissenting).
} 
to the religious conduct for non-religious reasons. From a liberal perspective, the question is whether the religious beliefs of individuals are implicated by regulation of a corporation. Because the majority shareholders have religious beliefs about how the corporation should act, regulation of the corporation implicates their religious liberty. The corporation may bring a claim because doing so promotes respect for the individuals who constitute the majority. ${ }^{130}$ Given this reason for recognizing standing, it is clear that the religious beliefs relevant to the claim should be those held by the majority. ${ }^{131}$

From an originalist or hybrid perspective, the question is whether the religious beliefs of the majority of owners are the religious beliefs that govern the corporation's conduct, or would govern it apart from government interference. Rule \#1 applies. ${ }^{132}$ A position taken by the majority of a corporation's owners as to the religious duties they consider binding on the corporation's actions is a claim that those beliefs govern the corporation, or at least would govern it absent regulation. This claim is presumably true because the majority legally controls the corporation's conduct. Assuming that the corporation's track record provides no reason to doubt the sincerity of this claim, a court would be justified in attributing the religious beliefs of

\footnotetext{
${ }^{130}$ In many cases, many of a corporation's owners may be institutions rather than individuals. This would render the analysis complex, as the religion of each institutional owner would need to be determined through an analysis that would parallel the analysis of the religion of the corporation bringing a claim. However, it would not impact the basic structure of the dignity-driven approach discussed here. Where owners have dignity that may be vindicated by a corporate claim, whether this dignity is enjoyed directly or derived from other individuals, corporate standing is justified by the owners' religious beliefs and the religious beliefs that pertain to the substantial burden analysis are those of the owners.

${ }^{131}$ The beliefs of the minority are irrelevant because it has been stipulated that these beliefs are not religious. Based on the dignity-driven perspective's definition of religion, this means that the minority does not have a dignitary interest in having its beliefs considered as relevant to the corporate claim, whether this is because the minority does not hold its views strongly enough to command respect or for some other reason.

${ }^{132}$ The originalist Rule \#1 is, "A corporation's claim that it holds the religious beliefs of those who exercise legal control over it is presumed to be an accurate indicator of the religious beliefs that it accepts as authoritative guides to conduct, but this presumption may be overcome by evidence of insincerity demonstrating that the company does not in fact follow the beliefs in question." Part III.B, supra. The hybrid Rule \#1 is, "A corporation's claim can be based on the religious beliefs of those who exercise legal control over it unless the company's record of conduct undermines the sincerity of the claim by showing that the company does not in fact follow the beliefs in question." Part IV.B, supra.
} 
the majority to the corporation. The rule-based analysis therefore concludes that the religious beliefs of the owners are relevant to the corporate claim because the owners speak for the corporation in identifying the beliefs that would govern corporate conduct absent regulation, whereas the balancing analysis reaches the same conclusion because the corporation can speak on the owners' behalf by seeking exemptions for their desired conduct. This distinction proves significant in assessing the next hypothetical.

As a second thought experiment, consider whether the analysis would be any different if the religious beliefs in question were those of a minority of a corporation's owners and the majority was indifferent to the proposed course of conduct. From a liberal perspective, this scenario is scarcely any different from the first. Just as before, the religious beliefs of individuals are implicated by regulation of the corporation and the corporation may represent the individuals by bringing a claim that vindicates their rights. The fact that the individuals in question are a majority in one case and a minority does not change the structure of the analysis.

From the other perspectives, however, this scenario is different from the first. It is subject to Rule \#2. ${ }^{133}$ Because the originalist and hybrid doctrines only allow individuals to speak for corporations in identifying the beliefs that would govern corporate conduct if they exercise actual control over the relevant actions, they would see the claim based on the beliefs of minority shareholders as weaker than one based on the beliefs of a shareholder block with legal authority over the corporation. Nevertheless, if the corporation's record of conduct provides adequate evidence that the majority allows the religious beliefs of the minority to bind the corporation, it

\footnotetext{
${ }^{133}$ The originalist Rule \#2 is, “A corporation's claim that it holds the religious beliefs of those who exercise influence but lack legal control over it is an unreliable indicator of the religious beliefs that it accepts as authoritative guides to conduct, but may be validated by evidence of sincerity demonstrating that the company does in fact follow the beliefs in question." Part III.B, supra. The hybrid Rule \#2 is, "A corporation's claim can be based on the religious beliefs of those who exercise influence but lack legal control over it only if the company's record of conduct validates the sincerity of the claim by showing that the company does in fact follow the beliefs in question." Part IV.B, supra.
} 
could be possible to attribute to the corporation the beliefs identified by the minority. Thus the rule-based analysis would view the second scenario as substantively different from the first, such that the beliefs of a majority of shareholders could be attributed to the corporation unless there is evidence that the corporation did not actually seek to follow those beliefs whereas the beliefs of a minority of shareholders could not be attributed to the corporation unless there was evidence that the corporation did seek to follow those beliefs.

Consider a third question. How should a court consider a corporation's claim for an exemption that would enable it to act in accordance with a doctrine common to the faiths of all its owners, although no single faith is subscribed to by a majority? From a liberal perspective, this scenario is scarcely any different from the first two. The corporate claim is justified as a means of vindicating the individual rights of the corporation's owners, and each owner's beliefs are relevant. If the beliefs of an unopposed minority in the second scenario were relevant to the corporation's claim, surely the support of other minorities should not make a minority's religious beliefs irrelevant here.

From an originalist perspective, this hypothetical raises a new difficulty. The originalist seeks to identify the religious beliefs of the corporation, and it is arguably not possible for a corporation to subscribe to multiple religions at one time. If the corporation cannot be described as a corporation with any particular faith, it is questionable whether it can be described as subject to duties imposed by a religion. Given the stipulation that the owners have different faiths, no single religion may be attributed to the corporation itself unless Rule $\# 2^{134}$ is satisfied by evidence from the corporation's historic practices showing that a single minority's religion has

\footnotetext{
${ }^{134}$ The originalist Rule \#2 is, “A corporation's claim that it holds the religious beliefs of those who exercise influence but lack legal control over it is an unreliable indicator of the religious beliefs that it accepts as authoritative guides to conduct, but may be validated by evidence of sincerity demonstrating that the company does in fact follow the beliefs in question." Part III.B, supra.
} 
been allowed to control its conduct as in the second scenario. ${ }^{135}$ This evidence would be hard to distinguish from evidence that the corporation attempted to accommodate multiple religions at once although it did not itself consider any particular set of religious obligations binding, so that outcomes would hinge on judicial decisions about how strongly a corporation's conduct should validate the sincerity of its claim.

A different difficulty would arise if a corporation refused to stipulate that its owners had different faiths. Judicial attempts to draw lines between religions in order to identify such situations would likely violate the Establishment Clause by entangling the government in judgments about the correctness of religious syncretism and about the significance of religious divisions that some would characterize as denominational and others would characterize as sectarian. ${ }^{136}$ Nevertheless, a court could perhaps question whether a corporation sincerely believes it is subject to duties imposed by a single religion if the relevant individuals see their religions as distinct. In that case, the corporate claim to follow a syncretistic religion would be ruled out by Rule \#3, which states that a corporation may only claim to be governed by religious beliefs held by some individual or group that controls or influences its conduct. ${ }^{137}$

The hybrid analysis would avoid these difficulties by focusing on individual beliefs rather than corporate beliefs. Rule \#1 would govern the situation in which a plurality of shareholders' religious beliefs support an exemption: A corporation's claim can be based on the religious beliefs of those who exercise legal control over it unless the company's record of conduct

\footnotetext{
${ }^{135}$ Whether the rights of individual owners may be vindicated by corporate claims as the dignity-driven perspective suggests or should be vindicated by individual claims is a different question. The duty-driven approach to religious exemptions is capable of justifying either approach. See text accompanying notes 82-83, supra.

${ }^{136}$ See, e.g., Bob Jones Univ. v. United States, 468 F. Supp. 890, 895 (D.S.C. 1978) rev'd, 639 F.2d 147 (4th Cir. 1980) aff'd, 461 U.S. 574 (1983) (attributing religious beliefs to Bob Jones University although it was nondenominational because it was "totally guided by its fundamentalist beliefs").

${ }^{137}$ See Part III.B, supra ("No record of potentially coincidental or strategic compliance with a religious belief can establish a corporation's religious belief absent a corporation's claim that it holds the religious beliefs of those who exercise legal control or influence over it.").
} 
undermines the sincerity of the claim by showing that the company does not in fact follow the beliefs in question. ${ }^{138}$ The religious beliefs of each individual in the plurality would be relevant to the corporate claim because the religious authority recognized by each individual would be countermanded by the challenged regulation. Thus, the hybrid analysis would see the claim based on a plurality's beliefs as substantively identical to the claim based on a majority's beliefs, and courts would have no need to explore the validity of a claim of syncretism.

A fourth hypothetical poses a more challenging problem for the liberal analysis than for the alternatives. Consider a corporation seeking an exemption that would enable it to act in accordance with the religious beliefs of a majority of its owners, although a minority of its owners object to the conduct for religious reasons. If minority shareholders had dignity that made their unopposed religious beliefs relevant to a corporation's claim in the second hypothetical, it seems that they have no less dignity — and therefore no less relevance — in this scenario. The liberal must treat both the majority and minority religious beliefs as relevant to the corporation's claim.

This raises the conceptual problem discussed in Part II.B of determining how to weigh the importance of conflicting religious beliefs. As discussed there, a majoritarian approach fails to meet the liberal's goal of maximizing respect for human dignity, ${ }^{139}$ and the best justiciable approach requires accounting for the different positions in which impacted individuals are

\footnotetext{
${ }^{138}$ Part IV.B, supra.

${ }^{139}$ In the corporate context, the word "majority" tends to be associated with shares rather than with individuals, suggesting an alternative type of "majoritarian" approach for resolving disputes among shareholders. The difficulty with a definition of "majority" that focuses on shares rather than individuals is that it would be possible for the dignity of a single individual to be treated as outweighing the dignity of any number of other individuals whether the court's rule is to prioritize the views of the minority or of the majority. From a dignity-centered perspective, this is only acceptable if the favored individual believe in a manner that commands greater respect (perhaps, for example, if he believes more deeply) than the others. An acceptable account of why those who hold the majority of shares should be treated with more dignity than those in the minority would involve an inquiry into how individuals who are situated in the majority are in a substantively different position than those situated in the minority-the same account considered and rejected in the remainder of this paragraph.
} 
situated relative to the challenged regulation. There could be an argument that majorities should be favored based on the assumption that those who are situated in a majority feel more intensely disrespected than those situated in a minority when the law prevents them from guiding a corporation's conduct according to their religious beliefs. This assumption could be grounded on the idea that majorities have more financial and emotional commitment to a corporation or on the idea that majorities feel a greater right to determine a corporation's course of conduct. But the dignity-driven perspective focuses on the rights of individuals — not of abstractions like majorities - and there is not necessarily any connection between being a member of a majority and the extent of one's financial and emotional stake in a corporation or the degree of one's control over it. Thus the liberal narrative provides no strong basis for allowing corporations to claim the religious beliefs of majority shareholders rather than those of minority shareholders.

The originalist and hybrid analyses of opposing religious beliefs among owners involve a straightforward application of Rule \#1. ${ }^{140}$ The inquiry is not into which individuals' beliefs are relevant to the corporation's claims, but into which religious beliefs in fact govern the corporation's conduct or would govern it absent government regulation. The scenario is one in which those who legally control the corporation's conduct have made statements about the religious beliefs that should guide the corporation. Absent evidence to the contrary in the corporation's record of conduct, it may be assumed that the majority shareholders seek to control the corporation's conduct in accordance with their statements of religious belief. Thus the religious beliefs that actually control the corporation or would control it absent regulation are

\footnotetext{
${ }^{140}$ The originalist Rule \#1 is, “A corporation's claim that it holds the religious beliefs of those who exercise legal control over it is presumed to be an accurate indicator of the religious beliefs that it accepts as authoritative guides to conduct, but this presumption may be overcome by evidence of insincerity demonstrating that the company does not in fact follow the beliefs in question." Part III.B, supra. The hybrid Rule \#1 is, "A corporation's claim can be based on the religious beliefs of those who exercise legal control over it unless the company's record of conduct undermines the sincerity of the claim by showing that the company does not in fact follow the beliefs in question." Part IV.B, supra.
} 
those articulated by the majority. Because the rule-based analysis seeks to identify who speaks on behalf of the corporation in identifying the beliefs that guide it rather than whose rights the corporation might be able to vindicate, disagreements among owners about the religious beliefs that should govern a corporation's conduct are a matter for the owners to resolve through corporate decision making processes rather than a matter for courts to resolve by identifying the owners whose dignity should be respected and the owners whose dignity can be ignored.

These hypotheticals illustrate the practical implications of the liberal, originalist, and hybrid approaches to religious liberty. The liberal treats as relevant the religious beliefs of every individual whose religious conduct may be impacted by a corporation's claim, but provides little basis for treating any individual's beliefs as more or less important than the beliefs of any other. This prevents it from distinguishing between the merits of a corporation's attempts to vindicate the religious liberty of a majority, of a minority, and of a plurality of its owners, and prevents it from developing a plausible means of arbitrating among owners with different religious views.

The originalist approach seeks to identify a single set of religious beliefs as attributable to the corporation based on statements about the beliefs that guide the corporation made by individuals who can credibly claim to speak on its behalf, considered in light of evidence that these statements are sincere. This enables it to attribute different degrees of weight to statements about the religious beliefs that govern a corporation made by a majority, by an active minority, and by a plurality. It also enables a straightforward approach to disputes among a corporation's owners that is in line with the suggestion in Hobby Lobby that state law regarding corporate governance applies to such disputes. ${ }^{141}$

\footnotetext{
${ }^{141}$ Hobby Lobby, 134 S. Ct. at 2775. From a dignity-centered perspective, the Court's suggestion would be much harder to explain.
} 
The hybrid approach is like the originalist approach in that it seeks to identify religious beliefs that guide corporate conduct based on statements about the beliefs that should guide the corporation and on the corporation's record of conduct. Its inquiry into actual control allows it to claim the same type of nuance and consistency with Hobby Lobby's statements about state law as the originalist can boast. However, because it seeks to vindicate individual religious liberty rather than corporate religious liberty, the hybrid approach avoids the need to identify a single set of religious beliefs as relevant and enables a more judicially manageable approach to situations in which a plurality of shareholders desire an exemption because of different religious beliefs. The sections that follow reinforce these observations about the superior nuance and manageability of the rule-based approaches to corporate sincerity as they explore the relevance of the beliefs of directors, managers, employees, customers, and founders.

\section{B. The Relevance of the Beliefs of Directors and Managers}

Three hypotheticals based on the facts of Hobby Lobby help highlight the differences between balancing and rule-based approaches to the role of directors and managers in identifying the religious beliefs relevant to a corporation's RFRA claim. ${ }^{142}$ First, consider whether the outcome would have been different if, prior to the case, the Greens had sold Hobby Lobby to shareholders who did not share their religious views but valued the Greens' experience and clearly stated a desire to allow the Greens to continue operating the company as they thought best in the capacity of directors and managers. From the liberal and hybrid perspectives, the corporate claim is justified as a means of vindicating individual rights. The individual right in

\footnotetext{
${ }^{142} I d$. at 2768 states, "protecting the free-exercise rights of corporations like Hobby Lobby, Conestoga, and Mardel protects the religious liberty of the humans who own and control those companies" (emphasis added), but provides no guidance on how the rights of those who control a corporation might be balanced against each other or against the rights of owners.
} 
question is the right of the Greens to act according to their religious beliefs, and the relevant religious beliefs are those of the Greens.

The originalist also concludes that the Greens' religious beliefs are the beliefs relevant to the claim, but reaches this conclusion because the Greens' beliefs are also the beliefs of the corporation rather than because they are the beliefs of individuals. Rule $\# 1^{143}$ applies because the Greens' statements of religious belief are statements about the beliefs that govern the corporation's conduct credibly made by those with legal authority over its conduct. Because control is not always correlated with ownership even in legal terms ${ }^{144}$ and the Greens rather than the shareholders exercise control over the relevant aspect of the corporation's conduct, they are able to speak on the corporation's behalf about the beliefs that guide its conduct. Absent evidence from the corporation's pattern of conduct showing that the Greens do not in fact control the corporation or do not control the corporation in accordance with their statements, the Greens' statements identify the religious beliefs that may be attributed to the corporation.

Second, consider whether the outcome would be changed if a minority of the new shareholders had believed for religious reasons that the corporation should provide full contraceptive coverage, but could not get a majority of the shareholders to support them against the Greens. From a liberal perspective, this scenario is difficult. Dignitary concerns are implicated on both sides of the question, presenting the same difficulties that arose in the earlier hypothetical about disputes among owners. This problem likely cannot be resolved from a liberal perspective unless an adequate number of individuals hold each relevant religious belief to justify the assumption that, on average, the proponents of each belief hold their beliefs with

\footnotetext{
143 "A corporation's claim that it holds the religious beliefs of those who exercise legal control over it is presumed to be an accurate indicator of the religious beliefs that it accepts as authoritative guides to conduct, but this presumption may be overcome by evidence of insincerity demonstrating that the company does not in fact follow the beliefs in question." Part III.B, supra.

${ }^{144}$ See Avi-Yonah, supra note 78.
} 
equal intensity. ${ }^{145}$ If this assumption can be justified in a given case, the liberal narrative calls for an analysis of how each individual's dignitary interest is impacted by the manner in which he or she is situated relative to the challenged regulation and requested exemption.

In this scenario, the liberal narrative requires courts to distinguish between the way that a regulation impacts a corporation's owners and the way it impacts a corporation's directors and managers. The key difference between the way owners are situated and the way those who operate a company are situated with respect to government regulation of the corporation is that those who operate the company are more directly responsible for implementing the regulation. Thus, a liberal court could plausibly count the dignitary interests of each of the Greens as stronger than the dignitary interests of each of the shareholders. After determining how much stronger each Green's interest is compared to each shareholder's interest, it would then go on to consider how many Greens would be impacted and how many shareholders would be impacted by a given outcome. This analysis may be flawed given that the dignitary interest in following one's religion may well have little to do the directness with which one is impacted by a regulation. Nevertheless, it is at least arguable that, in cases where a large number of individuals are involved on each side of a question, such an analysis may be defensible in a liberal narrative. From an originalist or hybrid perspective, a single mode of analysis is justified whether there are many individuals involved or few. As in the first scenario, the shareholders allow the Greens' beliefs to bind the corporation and the Greens' statements of their beliefs may be taken as the beliefs that govern the corporation's conduct unless there is evidence to the contrary. The fact that some shareholders object to the Greens' course of conduct does not make this scenario substantively different from the first, because the feelings of these shareholders do not impact what beliefs govern the corporation or would control its conduct absent government interference.

\footnotetext{
${ }^{145}$ See Part II.B, supra.
} 
Although a minority could, in other circumstances, claim to speak on behalf of the corporation because they have a measure of influence, they cannot speak on the corporation's behalf in a manner contrary to the Greens, whose claim is presumptively accurate because they continue to exercise legal control.

Consider a third scenario. In Hobby Lobby, the corporation unwittingly provided coverage for the forms of contraception to which it later objected, but terminated coverage as soon as it became aware of the situation. ${ }^{146}$ Would the analysis change if the facts of scenario two remained the same ${ }^{147}$ but it was also stipulated that the Greens had knowledge that the company provided full contraception coverage prior to litigation? From a liberal perspective, a key question would be whether the Greens had protested coverage. If not, the sincerity of the Greens' assertion of religious belief would fall into question. But if the Greens did object and the shareholders had insisted on providing coverage, their sincerity would not be questioned. The liberal would weigh their cumulative dignitary interests against the cumulative dignitary interests of the minority shareholders exactly as in the preceding scenario. In short, the corporation's record of conduct would have no impact on an analysis of its RFRA claims as long as the individuals involved were sincere in their beliefs.

As was noted in the discussion of scenario two, the originalist and hybrid analyses are impacted by a corporation's record of conduct. Because they seek to identify the religious beliefs a corporation accepts as authoritative guides to its conduct, evidence that a corporation has knowingly acted contrary to the beliefs that it claims to follow will bar the corporation's claim. This is a simple application of the principle that even the individuals who legally control a

\footnotetext{
${ }^{146}$ Verified Complaint at 14-15, Hobby Lobby v. Sebelius, 870 F.Supp.2d 1278 (W.D.Okla. 2012), No. CIV-121000-HE (Sept. 12, 2012).

${ }^{147}$ Namely, if the Greens did not own Hobby Lobby, a minority of Hobby Lobby's shareholders believed for religious reasons that the corporation should provide full contraceptive coverage, and the Greens had been retained as directors and managers.
} 
corporation cannot credibly claim that the corporation accepts their religious beliefs as binding if its record of conduct shows it does not in fact follow those beliefs. ${ }^{148}$

\section{The Relevance of the Beliefs of Employees}

It is possible, and arguably desirable, for corporations to exist in part for the purpose of benefitting their employees - in some cases, for the purpose of providing individuals the opportunity to be employed in an industry where they otherwise would have difficulty finding employment. ${ }^{149}$ For example, a bank could provide loans in a manner consistent with the Muslim teaching against charging interest as a service not only to Muslim customers but also to Muslim professionals seeking to enter the banking industry. If the federal government passed a consumer protection law requiring banks to publish the effective rate of interest on all loans issued and Muslims believed this practice to be contrary to the teachings of Islam, such a bank could potentially seek a religious exemption.

From a liberal perspective, the bank could justify its claim as a means of protecting the religious liberty of Muslim bankers. ${ }^{150}$ The dignitary interests and religious beliefs involved are clearly those of the bankers. Muslim bankers are situated in the same position relative to the regulation as Muslim bank directors and managers would be: The regulation confronts them with

\footnotetext{
${ }^{148}$ The originalist Rule \#1 is, “A corporation's claim that it holds the religious beliefs of those who exercise legal control over it is presumed to be an accurate indicator of the religious beliefs that it accepts as authoritative guides to conduct, but this presumption may be overcome by evidence of insincerity demonstrating that the company does not in fact follow the beliefs in question." Part III.B, supra. The hybrid Rule \#1 is, “A corporation's claim can be based on the religious beliefs of those who exercise legal control over it unless the company's record of conduct undermines the sincerity of the claim by showing that the company does not in fact follow the beliefs in question." Part IV.B, supra.

${ }^{149}$ Hobby Lobby, 134 S. Ct. at 2768 may have implied that the beliefs of employees can be relevant to corporate RFRA claims when it observed that corporations are only capable of holding beliefs and performing actions when viewed together with "the human beings who own, run, and are employed by them." However, it provided no guidance on how their rights should be weighed against the rights of other corporate constituents. One laudable example of a corporation existing in part to benefit a disadvantaged group of employees from outside the potentially contentious sphere of religion is provided by the spread of restaurants that make interacting with wait staff using sign language a part of the dining experience in part to increase employment opportunities for the deaf and mute. ${ }^{150}$ The claim could also be based on the dignity of Muslim clients or on both the dignity of clients and bankers, but this analysis seeks to isolate the relevance of employee's religious beliefs from other factors.
} 
a choice between retaining their jobs and following their religion. Thus, the beliefs of bankers relate to the corporate claim in exactly the same way that the beliefs of the bank's operators would, and the claim based on the beliefs of Muslim employees is no different than one based on the beliefs of Muslim owners, directors, or managers.

The rule-based analyses provide a more persuasive account of how the position in which employees are situated might impact the analysis. A corporation's employees differ from its owners, directors, and managers in that they have no legal control over the corporation's conduct. Therefore, the bankers' statements about the religious beliefs that should guide the corporation may well be individual beliefs that do not govern the corporation and that would not control its conduct even in the absence of government regulation. Pursuant to Rule \#2, the religious beliefs that bankers believe should control the corporation cannot be attributed to the corporation unless the bankers have some influence over the corporation and there is adequate evidence that the company does in fact seek to follow the beliefs in question. ${ }^{151} \mathrm{~A}$ few bankers in a large bank may have so little influence that no amount of evidence regarding sincerity could prove that they spoke on behalf of the corporation as those with de facto control over its conduct. ${ }^{152}$ However, if a large number of the bankers are Muslim, their collective influence may be great and evidence from the bank's pattern of conduct may justify an originalist court's inference that the corporation accepts their beliefs as binding on its action or a hybrid court's

\footnotetext{
${ }^{151}$ The originalist Rule \#2 is, “A corporation's claim that it holds the religious beliefs of those who exercise influence but lack legal control over it is an unreliable indicator of the religious beliefs that it accepts as authoritative guides to conduct, but may be validated by evidence of sincerity demonstrating that the company does in fact follow the beliefs in question." Part III.B, supra. The hybrid Rule \#2 is, "A corporation's claim can be based on the religious beliefs of those who exercise influence but lack legal control over it only if the company's record of conduct validates the sincerity of the claim by showing that the company does in fact follow the beliefs in question." Part IV.B, supra.

${ }^{152}$ The question would be whether the bankers collectively exercise so little control that they cannot credibly claim to speak on behalf of the bank in identifying its religions beliefs. If no claim has been made on behalf of the corporation, Rule \#3 applies. Compliance with a set of religious beliefs may be fortuitous and cannot, on its own, justify a claim. See Parts III.B and IV.B, supra.
} 
inference that the corporation would follow their beliefs absent government interference. The rule-based approaches recognize the significance of employees' varying degrees of influence over a corporation in determining whether their beliefs are relevant to a corporate religious liberty claim, whereas the balancing approach treats every individual's belief as relevant simply by merit of the individual being impacted by the proposed exemption.

This difference may have dramatic implications. Consider, for example, whether the analysis above would be any different if the employees who objected to the consumer protection law were Muslim janitors who did not believe they should work for a corporation that did not follow Muslim teachings. From a liberal perspective, their beliefs are arguably just as relevant to the corporate claim as the beliefs of any bankers with conscientious objections, because they, like the bankers, would be enabled to follow their religion at work if the corporation received an exemption. ${ }^{153}$ From an originalist or hybrid perspective, their beliefs are likely irrelevant because a claim that the janitors influence the corporation's understanding of how it should conduct its banking practice lacks credibility. Rule \#3 applies, with its stipulation that no amount of conduct consistent with a religious belief establishes a corporation's acceptance of that belief absent a claim to that effect made on behalf of the corporation by those who exercise influence or control over the corporation. ${ }^{154}$ The question whether the beliefs of bankers may be distinguished from those of janitors highlights the fact that the liberal narrative cannot treat the religious beliefs of any impacted individuals as irrelevant and struggles to explain why any beliefs might be more

\footnotetext{
${ }^{153}$ It might be argued that the janitors are less likely to feel intensely disrespected because they are not directly impacted by the regulation. But it is not clear why a Muslim required to actively engage in the activity of banking contrary to his or her religious beliefs should feel any more disrespected than a Muslim required to actively engage in the activity of cleaning for a bank contrary to his or her religious beliefs. Because the janitors' belief in this scenario is that working for the bank is wrong, the burden may well be indistinguishable from the burden on the banker.

${ }^{154}$ See Parts III.B and IV.B, supra.
} 
relevant than others, whereas the accounts focused on the actual influence of religious beliefs on corporate conduct provides clear rules for making intuitive distinctions.

\section{The Relevance of the Beliefs of Customers}

Some corporations may exist in part for the purpose of providing customers with products that satisfy religious requirements. Such corporations may seek to bring religious liberty claims based on the religious beliefs of their customers. For example, a kosher butcher shop may seek an exemption from animal cruelty laws prohibiting butchering practices required by Jewish teaching, even if those who own, operate, and are employed by the company are not Jewish. In a liberal narrative, the beliefs of the customers are relevant to the claim for the same reason that the beliefs of owners, operators, or employees would have been if any of them were Jewish — the corporate claim influences their practice of religion. The customers are in a different position than the shop's operators and employees because they are faced with the choice of following their religion or giving up meat whereas the others would have been faced with the choice of following their religion or giving up their livelihood. But the burden on their exercise of religion is still substantial and provides a solid basis for the claim - a stronger basis, arguably, than could be derived from the rights of owners if the shop's owners had been Jewish but held ownership shares in other businesses so that their livelihood was not at stake.

The originalist and hybrid narratives would agree that the religious beliefs of the corporation's customers provide a basis for the corporate claim, but would be able to distinguish the relevance of customer's beliefs from the relevance of beliefs that other stakeholders might have. The first inquiry would be into the relationship of the customers to the corporation. If a large portion of the shop's customers are Jewish, they will be influential but will lack legal control, making Rule \#2 applicable, with its presumption that the customers' religious beliefs are 
private beliefs not attributable to the corporation absent contrary evidence in the corporation's record of conduct. ${ }^{155}$ An inquiry into a kosher butcher shop's record of conduct will show compliance with Jewish law, and the presumption will be overcome. Like the liberal narrative, the originalist and hybrid narratives support finding Jewish teaching relevant to the corporate claim on the basis of the customers' faith.

The liberal account and the accounts focused on actual control diverge, however, in more complex scenarios. Consider, for example, whether the analysis would be impacted by the fact that a cashier at the butcher shop was unaware of the conditions of kosher slaughter until litigation highlighted the issue, but has sincere religious convictions against what he considers to be animal cruelty. In a liberal narrative, the cashier's religious beliefs are relevant to the corporation's claim because his religious liberty is implicated by the requested exemption. His dignitary interest is arguably greater than that of the customers because of the position in which he is situated. Losing the case from his perspective would mean losing his job or violating his conscience whereas losing the case from the customers' perspective would mean "only" a change in diet. A court would be called upon to balance the strong dignitary interest of one cashier against the weaker dignitary interest of multiple customers. Depending on how many cashiers and customers are involved, the kosher butcher shop could have standing to seek an accommodation of Jewish practices or could be limited to claiming the religious beliefs of some other group that opposed kosher slaughter.

In a narrative focused on the actual control a belief exercises over corporate conduct, the beliefs of the cashier are clearly not relevant in the same way as the beliefs of the customers. Although the impact of the regulation on other members of society, including the cashier, could be considered in evaluating whether the regulation is narrowly tailored to serve a compelling

\footnotetext{
${ }^{155}$ See Parts III.B and IV.B, supra.
} 
state interest, a kosher butcher shop would never be treated as having standing to protect the religious liberty of the cashier against those who desire to practice the Jewish faith. Because the cashier cannot credibly claim that his beliefs influence or control the corporation, he cannot speak on its behalf and identify its religious beliefs, as stated by Rule \#3. ${ }^{156}$ Once again, the originalist and hybrid approaches to religious liberty explain intuitive distinctions that the liberal approach struggles to understand.

\section{E. The Relevance of the Beliefs of Founders}

The Supreme Court's reference in Hobby Lobby to benefit corporations as an example of corporations that exercise religion ${ }^{157}$ suggests a final category of actors whose beliefs may be relevant to a corporation's claims. The founders of a benefit corporation establish it with a charter that defines its purposes. If the founders choose a religious purpose, that purpose may form the basis of the corporation's claim. In a liberal narrative, allowing the corporation to bring a claim vindicates the individual religious liberty of the corporation's founders. If the founder is no longer living and its owners, operators, employees, and customers do not share the founders' beliefs, forcing the corporation to act contrary to a religious purpose established in its charter would not cause that individual to lose his or her sense of wellbeing and fulfillment.

Nevertheless, the rule that the religious beliefs a corporation's founder articulates in its charter remain relevant to the corporation's claim after the founder's death might be defended as a means of giving the founder confidence before death that the legal system respected his rights. ${ }^{158}$

\footnotetext{
${ }^{156}$ The originalist Rule \#3 is, "No record of potentially coincidental or strategic compliance with a religious belief can establish a corporation's religious belief absent a corporation's claim that it holds the religious beliefs of those who exercise legal control or recognizable influence over it." Part III.B, supra. The hybrid Rule \#3 is, "A corporation's claim cannot be based on a record of potentially coincidental or strategic compliance with a religious belief not held by an individual who exercises legal control or recognizable influence over the relevant corporate conduct." Part IV.B, supra.

${ }^{157}$ Hobby Lobby, 134 S. Ct. 2751, 2771 (2014).

${ }^{158}$ This argument might raise concerns about dead-hand control, however.
} 
Although this dignitary interest might not be strong, it would at least explain the ongoing relevance of the corporate charter to the corporation's religious liberty claim.

In an originalist or hybrid analysis, the charter relates to the corporation's RFRA claim as a statement of principles and purposes that govern the corporation's conduct. Regardless of whether or not the founder is still alive or any other currently living stakeholder holds the religious belief in question, the corporate charter gives the religious beliefs of the founder control over the corporation's actions. Pursuant to Rule $\# 1,{ }^{159}$ the religious beliefs that the charter identifies as authoritative guides to corporate conduct are presumptively attributable to the corporation because of this legal control. The presumption in Rule \#1 may be overcome by evidence that the corporation has a record of conduct not in accordance with the religious beliefs identified in the charter. If the charter has become a dead letter to which the corporation pays little attention, its legal control falls short of actual control, which is the true indicator of what beliefs may be attributed to the corporation. This caveat to the conclusion that the corporate charter can identify the religious beliefs relevant to the corporation's claim is unjustifiable in a liberal narrative.

If the founder is still alive and retains control of the company, the liberal could understand a change in a corporation's conduct as an indication of change in the founder's beliefs. But the founder's dignitary interest in knowing that the corporation will continue to pursue his vision after he dies runs contrary to a rule that would recognize the capacity of a corporation to reject the religion established in its charter after his death. The liberal narrative

\footnotetext{
${ }^{159}$ The originalist Rule \#1 is, “A corporation's claim that it holds the religious beliefs of those who exercise legal control over it is presumed to be an accurate indicator of the religious beliefs that it accepts as authoritative guides to conduct, but this presumption may be overcome by evidence of insincerity demonstrating that the company does not in fact follow the beliefs in question." Part III.B, supra. The hybrid Rule \#1 is, "A corporation's claim can be based on the religious beliefs of those who exercise legal control over it unless the company's record of conduct undermines the sincerity of the claim by showing that the company does not in fact follow the beliefs in question." Part IV.B, supra.
} 
can only consider actual practices relevant to the extent they shed light on the sincerity of the beliefs of individuals. For this reason, it can provide no account like that provided by the originalist and hybrid narratives of why a corporation's conduct after the death of its founder should have any impact on the religious beliefs relevant to its claim.

\section{CONCLUSION}

The liberal narrative provides an inadequate account of why, when, and how individual beliefs are relevant to corporate claims. In this narrative, individual beliefs are relevant because corporate claims are simply substitutes for attempts by individuals to defend their own dignity. Individual beliefs are relevant when they happen to be held by the coalition of individuals with the greatest accumulation of intense feelings regarding corporate conduct. Individual beliefs become relevant by outweighing other beliefs in an ad hoc balancing of dignitary interests among large groups of individuals (and in no explicable way when small groups of individuals disagree). Although this narrative's individualism may be popular and fits well with some of the rhetoric in Hobby Lobby, it supports an unmanageable balancing doctrine that does not fit existing law and that fails to make intuitive distinctions.

The originalist narrative provides an alternative account of the relationship between individual beliefs and corporate claims that better fits existing law. It explains that individual beliefs are relevant because corporations can accept beliefs held by individuals as identifying the religious duties that should govern their conduct. It treats individual beliefs as relevant when they can be fairly attributed to corporations on the basis of their actual control over corporate conduct. And it provides three straightforward doctrinal rules for testing how well a corporation's actual practices corroborate the sincerity of religious beliefs attributed to the corporation by those claiming to speak on its behalf. This account provides an explanation of 
why corporate claims should be recognized in addition to individual claims and justifies a nuanced doctrinal analysis that is in line with the substantive analysis in Hobby Lobby and the nonprofit cases, but is also in tension with Hobby Lobby's individualistic rhetoric.

Justice Kennedy's hybrid narrative agrees with liberals that corporate claims exist to protect individual rights but agrees with originalists that the relevant individual beliefs are those that actually control a corporation's conduct, or would control it absent government interference. It articulates the popular liberal justification of corporate standing in terms of a dignity derived from duty so that it is acceptable to originalists as well as to liberals. But instead of using this justification to support an unmanageable doctrine of sincerity, it suggests a nuanced doctrine that shares the originalist focus on a belief's actual control over corporate conduct and shares its fit with existing law.

In marrying the virtues of liberalism and originalism, Justice Kennedy's narrative avoids their vices. The liberal struggles to explain which individuals' religious liberty a corporate claim should vindicate when different individuals hold conflicting beliefs. Justice Kennedy can answer that the only relevant beliefs are the ones burdened by an exercise of governmental authoritythat is, the beliefs that would have guided a corporation's conduct if the government had not acted in the challenged manner. Instead of balancing competing dignitary interests, therefore, courts can pursue an inquiry into whose religious beliefs guide corporate conduct—an inquiry like that of the originalist.

Unlike the originalist, however, Justice Kennedy can explain why the inquiry is limited to beliefs that guide corporate conduct without being forced into the slightly awkward position that religious beliefs may be attributed to corporations. The originalist relies on a specialized definition of belief to explain how corporations can have religious beliefs and why corporate 
religious liberty matters. Justice Kennedy avoids the challenge by granting that the corporation has no beliefs or rights as a corporate entity, but that courts are concerned with the religious beliefs that govern corporate conduct because those are the beliefs that could be burdened by government regulations of corporations. Beliefs that did not guide corporate conduct were burdened by private decision makers rather than by government and are therefore irrelevant to the corporate claim.

The liberal narrative offers a popular justification of corporate religious liberty claims and a doctrine that does not fit existing law. The originalist narrative offers a justification of which many are suspicious but uses it to defend a doctrine that does fit existing law. Both struggle to reconcile the individualistic rhetoric of Hobby Lobby with more substantive legal doctrine. But Justice Kennedy's concurrence resolves these apparent tensions, suggesting a hybrid narrative that justifies corporate claims at the same time that it explains existing doctrine. It is Justice Kennedy's narrative that most persuasively shows the way forward into the next chapter of the doctrine of corporate religious liberty in America. 